\title{
1. LATE NEOGENE AND QUATERNARY SEDIMENTATION ON THE CONTINENTAL SLOPE AND UPPER RISE OFFSHORE SOUTHEAST GREENLAND: INTERPLAY OF CONTOUR AND TURBIDITY PROCESSES ${ }^{1}$
}

\author{
Lene Clausen ${ }^{2}$
}

\begin{abstract}
Three seismic sequences have been identified within the late Neogene and Quaternary deep-sea sedimentary succession on the continental slope and rise in the Irminger Basin offshore southeast Greenland. They are bounded at the base by unconformities of middle Pliocene, early Pliocene, and (?) late Miocene ages, respectively. The sequences form large, elongate drifts on the seafloor, oriented almost perpendicular to the continental rise. The seismic facies of the two youngest sequences suggest mixed deposition both from contour and turbidity currents off the then glaciated shelf. Inter-drift channel-levée complexes recognized within the youngest sequence (middle Pliocene-Pleistocene) were deposited from turbidity currents. The major turbidity channels, originating at the base of the continental slope, are prolongations of transverse shelf trough/trough-mouth fan systems. A moat zone separates the elongate drifts from the continental slope. The depth stratum of the modern southward-flowing deepsea contour-currents correlates with the position of this moat zone. It is concluded that the Labrador Sea Water Current has played a far more important role in sculpturing the continental slope and rise than earlier recognized. Mixed depositional systems as described in this paper might prove to be a widespread feature at high-latitude glaciated margins.
\end{abstract}

\section{INTRODUCTION}

The study area is located in the western Irminger Basin off the southeast Greenland continental margin (Fig. 1). The study is based on multichannel reflection seismic data acquired by the NAD-Project (Larsen, 1985; Larsen, 1990) and the NARM-Project (Larsen et al., 1993), and ODP Leg 152 bore-hole data (Larsen, Saunders, Clift, et al., 1994). The main objective of the present paper is to describe depositional and erosional features on the slope and rise and to discuss the nature of the upper Neogene and Quaternary sediments, their deposition, and their palaeoceanographic implications. Interpretations are based on seismic stratigraphic analysis combined with seafloor morphology and drilling data.

The deep-sea sedimentary succession under consideration appears to be dominated by contourites and turbidites. Clastic deep sea sediments deposited by turbidity currents are quite extensively documented (see review by Mutti, 1992), whereas contour-current-controlled deposition is less well studied (for a recent review, see Faugères and Stow, 1993). A number of authors have formulated lithologic criteria for distinction of turbidites from contourites (Hollister and Heezen, 1972; Lovell and Stow, 1981; Stanley, 1993; among others), but differences are commonly quite subtle, because contourites can result from reworking of older turbidites, or "piracy" of sediment directly from turbidity currents, or fluctuating contourcurrents may mimic the grading patterns characteristic of turbidites (Pickering et al., 1989). There is a consensus that both alongslope and downslope processes are important for the development of continental slopes (e.g., Asquith, 1979; Kuijpers and Duin, 1986; Tucholke and Mountain, 1986; Myers and Piper, 1988), but distinction between the two processes at the level of seismic and sediment facies is difficult and largely circumstantial. In the present context both processes are likely to operate and are inferred to have occurred based on seafloor topography and the seismic facies distribution.

${ }^{1}$ Saunders, A.D., Larsen, H.C., and Wise, S.W., Jr. (Eds.), 1998. Proc. ODP, Sci. Results, 152: College Station, TX (Ocean Drilling Program).

${ }^{2}$ Geological Museum, University of Copenhagen, Øster Voldgade 5-7, DK-1350 Copenhagen K, Denmark. lenec@savik.geomus.ku.dk

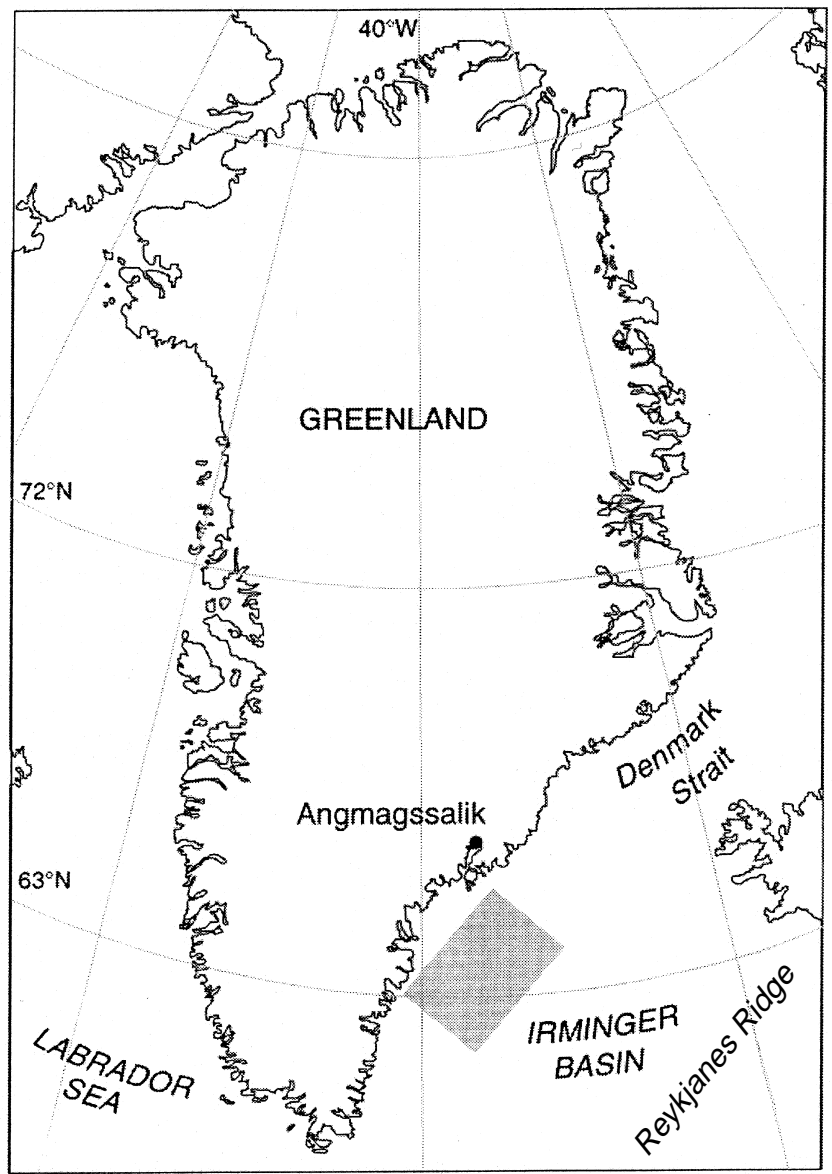

Figure 1. Location of the Irminger Basin bounded northward by the Denmark Strait Sill forming part of the Faroe-Iceland-Greenland Ridge and eastward by the Reykjanes Ridge. The Irminger Sea connects southward to the Labrador Sea. The study area (enlarged in Fig. 2) is indicated. 


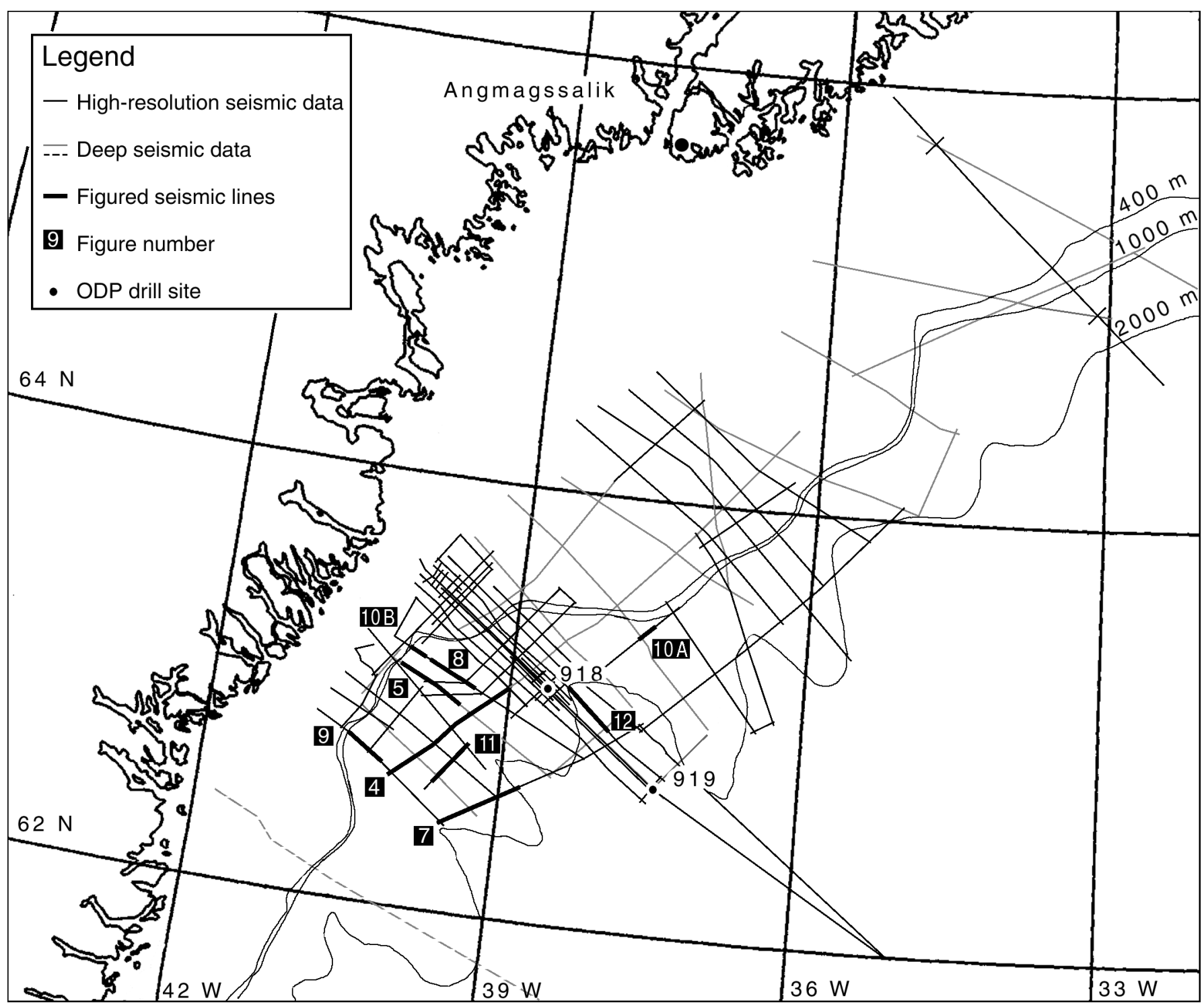

Figure 2. Map of study area showing the grid of multichannel seismic data and simplified bathymetry. The 400-m isobath marks the position of the shelf break. Figured line segments are highlighted, and relevant ODP drill sites are indicated. The dashed line represents a deep seismic line of the ICE Survey (Larsen et al., 1995).

The study area is difficult to access, but a fair amount of previous work has been done. Sommerhoff $(1973,1979)$ and Johnson et al. (1975), based on a detailed study of the bottom topography, considered the seafloor morphology on the shelf and continental slope to be glacially formed and modified by turbidity- and contour-current erosional processes. Their observations are largely confirmed by the present study. Considerable deposition by contour-currents was previously thought to take place only south of Cape Farewell on the Eirik Ridge (Johnson and Schneider, 1969; Jones et al., 1970; Ruddiman, 1972; Egloff and Johnson, 1975). However, both erosion and deposition by contour-currents were believed by Larsen (1990, fig. 8 ) to take place in the deep sea environment since the late MiocenePliocene. A tentative seismic stratigraphy for the Cenozoic sedimentary succession of the southeast Greenland shelf and rise was established by Larsen $(1985 ; 1990)$. The Quaternary geology of the Greenland shelves is reviewed by Funder and Larsen (1989). Preliminary interpretations of the Neogene development of the shelf can be found in Larsen et al. (1994) and Lykke-Andersen (this volume). It is doc- umented in these studies that the Greenland continent has experienced glaciation back to the late Miocene ( $7 \mathrm{Ma}$ ) and that the shelf has prograded considerably because of glacial advances across the shelf.

\section{SEISMIC DATA}

The seismic grid covers an area extending from the mid shelf to the upper continental rise, but only data from the continental slope and rise are discussed (Fig. 2). The study is based on approximately $2500 \mathrm{~km}$ of high resolution, relatively shallow seismic profiles and approximately $700 \mathrm{~km}$ of conventional seismic profiles, referred to as deep seismic profiles.

The high resolution seismic data were acquired with an acoustic source consisting of four 40-in ${ }^{3}$ sleeve guns and a $143.75 \mathrm{~m}$ long 24channel streamer (Marstal, 1993; 1994). The vertical resolution is estimated at $5 \mathrm{~m}$ in the shallow part of the profiles, and the penetration 


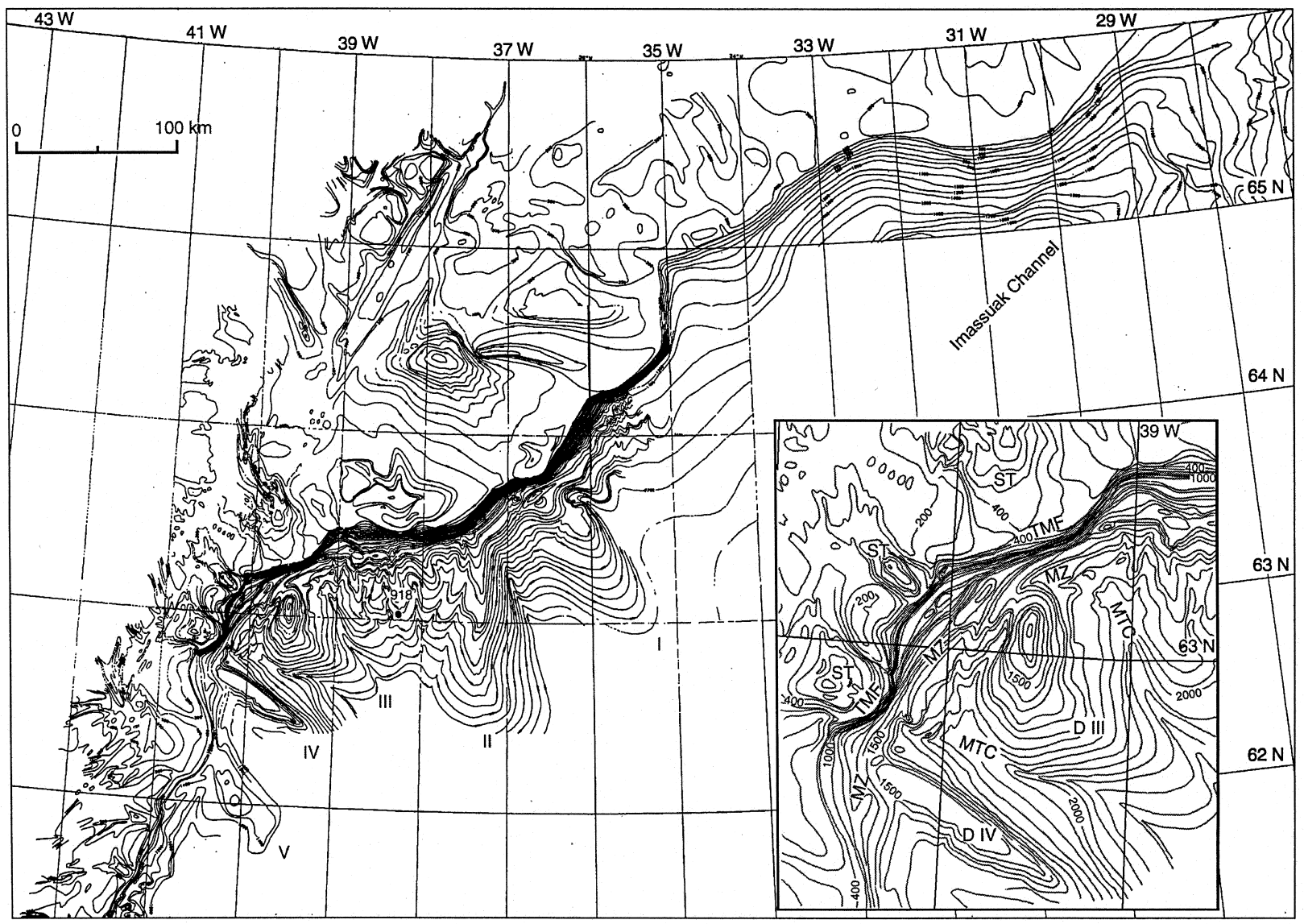

Figure 3. Map showing the bathymetry of the southeast Greenland shelf, continental slope, and rise based on a compilation of all available data. Isobaths for every $50 \mathrm{~m}$ are indicated in the study area, whereas $100 \mathrm{~m}$ isobaths are indicated north of $64^{\circ} 30^{\prime}$ and south of $62^{\circ} 30^{\prime}$. Site 918 is marked. Note the change from a gently slanting seafloor north of $65^{\circ} \mathrm{N}$ to the steep continental slope and gently dipping continental rise developed south of this latitude. Morphological elements are marked in the enlarged insert: transverse shelf troughs (ST), trough-mouth fans located at the continental slope (TMF), moat zone and associated mounds located at the base of the continental slope (MZ), elongate drifts numbered I-V, located on the upper continental rise (D), and major turbidity channels (MTC) with associated subsidiary channels located between the sediment ridges on the upper continental rise.

depth on the continental rise is approximately $2 \mathrm{~s}$ two-way traveltime (TWT) or first seabed multiple. The seismic data were processed by the Geological Institute, University of Aarhus (Marstal, 1993; 1994). The deep seismic data were acquired by a large array of airguns ( 3600 or more cubic inch) and recorded by a $2.4-4.8 \mathrm{~km}$ long streamer (Larsen, 1990; Larsen et al., 1995). The data were processed to $7 \mathrm{~s}$ TWT.

Thicknesses of seismic sequences and units in the following descriptions are based on the preliminary TWT vs. depth relationship at Site 918 (Larsen, Saunders, Clift, et al., 1994) calibrated to acoustic velocities adopted from the GGU 1981 seismic survey (Larsen, 1990). Seismic velocities of $1700 \mathrm{~m} / \mathrm{s}$ and $1750 \mathrm{~m} / \mathrm{s}$ TWT have been used for Sequence $\gamma$ and for $\alpha$ and $\beta$, respectively. For water a seismic velocity of $1480 \mathrm{~m} / \mathrm{s}$ has been used.

\section{MORPHOLOGY OF THE CONTINENTAL SLOPE AND RISE}

Detailed bathymetric information between $64^{\circ} \mathrm{N}$ and $62^{\circ} 30^{\prime} \mathrm{N}$ is provided by the recent high resolution seismic surveys in combination with older bathymetric data (Fig. 3). The morphological elements recognized on the slope and rise include trough-mouth fans (TMF), elongate drifts (D), moat zone (MZ), and major turbidity channels (MTC); transverse troughs (ST) occur on the shelf (Fig. 3). These elements correspond to the features observed by Sommerhoff (1973) and Johnson et al. (1975), but the additional bathymetric information provides a better 3D picture of the morphology.

The continental slope and rise immediately south of the Denmark Strait comprise one single morphological unit, dipping about $2^{\circ}-3^{\circ}$ toward the southeast. Southward of approximately $65^{\circ} \mathrm{N}$, a steep continental slope, sloping $6^{\circ}-13^{\circ}$ (locally as much as $17^{\circ}$ ), can be distinguished from a continental rise dipping $1.5^{\circ}$ toward the east and southeast. The continental slope is characterized by bathymetric bulges located in front of distinct, transverse shelf troughs and which are referred to as trough-mouth fans (TMF) (Vorren et al., 1989) (Fig. 3).

On the upper continental rise five elongate drifts (Roman numbers I to V on Fig. 3) separated by interjacent downslope channels have been identified; additional drifts occur to the north and to the south of the study area (Johnson et al., 1975). The described drifts, which are about $30 \mathrm{~km}$ across and some 40-60 km long, display a relief of at least $400 \mathrm{~m}$. They are located slightly to the south of the neighboring transverse shelf trough/trough-mouth fan systems and are oriented almost perpendicular to the continental slope, from which they are separated by contour parallel channels (moats). The elongate drifts exhibit a transverse and a longitudinal asymmetry (Figs. 4, 5). Thus the north flank is steep and typically slightly concave-up, whereas the 

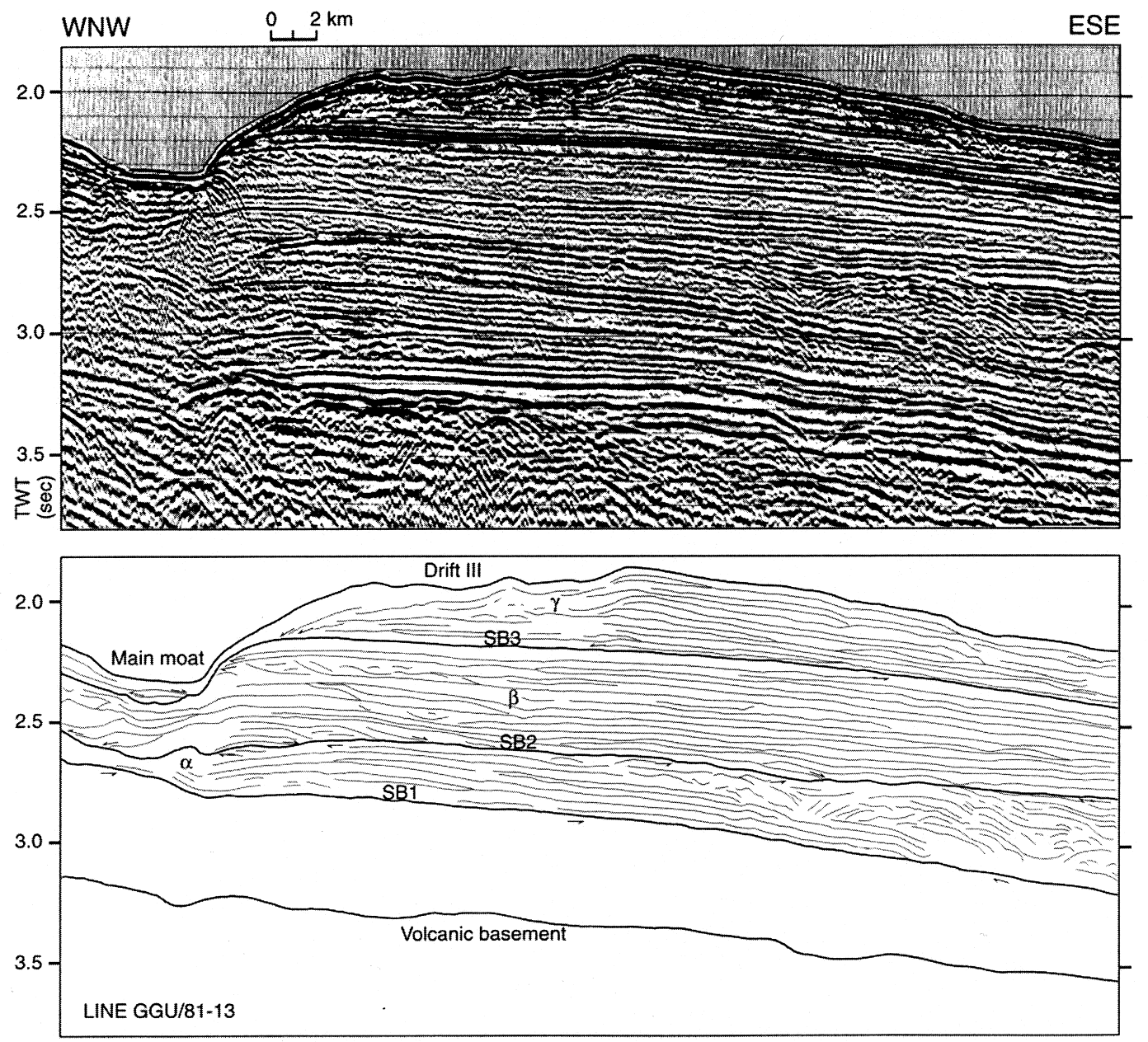

Figure 4. Deep seismic profile and interpreted line drawing illustrating the morphology and internal architecture of the elongate drifts (for location see Fig. 2). The data show a cross section of drifts III and IV separated by a channel-levée domain. The drifts are 30-40 km wide, 50-60 km long, and display a relief of as much as $450 \mathrm{~m}$. The two elongate drifts consist of three seismic sequences $(\alpha, \beta$, and $\gamma)$ defined by their seismic facies configuration and bounding unconformities (SB1-3). See also Figure 5 for a crossing line (dip-profile).

south flank is convex and less steep, and a steep slope characterizes the western termination adjacent to the moat, whereas the eastern flank slopes very gently.

A zone, $15-25 \mathrm{~km}$ wide, characterized by a complex morphology of sediment mounds and interjacent moats, lies at the base of the upper slope at a water depth of $1000 \mathrm{~m}$ to $1700 \mathrm{~m}$. It can be traced along the continental slope for as much as $250 \mathrm{~km}$ (Fig. 3). The individual moats within the zone are $0.5 \mathrm{~km}$ to $6 \mathrm{~km}$ wide, and range from broad shallow depressions to deep well-defined scours. The moat zone comprises a downslope main moat flanked upslope by a few smaller moats interspersed by sediment mounds. These vary in size and geometry from small isolated mounds, $30-70 \mathrm{~m}$ high and $2-3 \mathrm{~km}$ across, to larger elongate contour parallel sediment drifts, $200 \mathrm{~m}$ high, 4-7 km across, and as much as $20 \mathrm{~km}$ long. Some mounds are symmetric, but most are characterized by a steep upslope limb and a gently dipping downslope limb. The moat-mound zone displays the most irregular relief seaward of the shelfal embayment (Fig. 3).

The elongate drifts are separated by major turbidity channels, commencing at the base of the trough-mouth fans. The major channels, which appear to be even better developed to the south of the study area, are as much as $150 \mathrm{~m}$ deep and $1-3 \mathrm{~km}$ wide, but the relief generally decreases downslope. Between drifts II and III smaller subsidiary turbidity channels originate from the base of the continental slope somewhere within the moat-mound zone at a water depth of ap- proximately $1500 \mathrm{~m}-1600 \mathrm{~m}$ (Fig. 3). Both the major and the subsidiary channels are comparatively straight, $\mathrm{U}$ - or V-shaped, and flanked by levées. The westerly levées are better developed than their eastern counterparts.

\section{MODERN DEEP-SEA CURRENTS IN THE IRMINGER BASIN}

A few long-term measurements have been made of bottom-current activity associated with deep current-controlled sedimentation, notably in the western Central and North Atlantic (McCave and Tucholke, 1986). Thus long-term current measurements and other hydrographic observations are available for the present study area (Fig. 6A). The North Atlantic Deep Water (NADW) is considered to comprise three main water bodies (Fig. 6B): A thin layer of dense, comparatively fresh Denmark Strait Overflow Water (DSOW) blanketing the lower continental rise, overlain by more saline water derived from the remote Iceland-Scotland overflows (ISOW), in turn capped by the core of relatively fresh Labrador Sea Water (LSW) (Livingstone et al., 1985; Dickson and Brown, 1994). At Dohrn Bank (transect A$\mathrm{A}^{\prime}$, Fig. 6A), the overflow totals 5.6 Sverdrups (Sv), but at some point around $64^{\circ} \mathrm{N}$ latitude the deep transport increases rapidly due to merging with other NADW components, of which the cold LSW may 

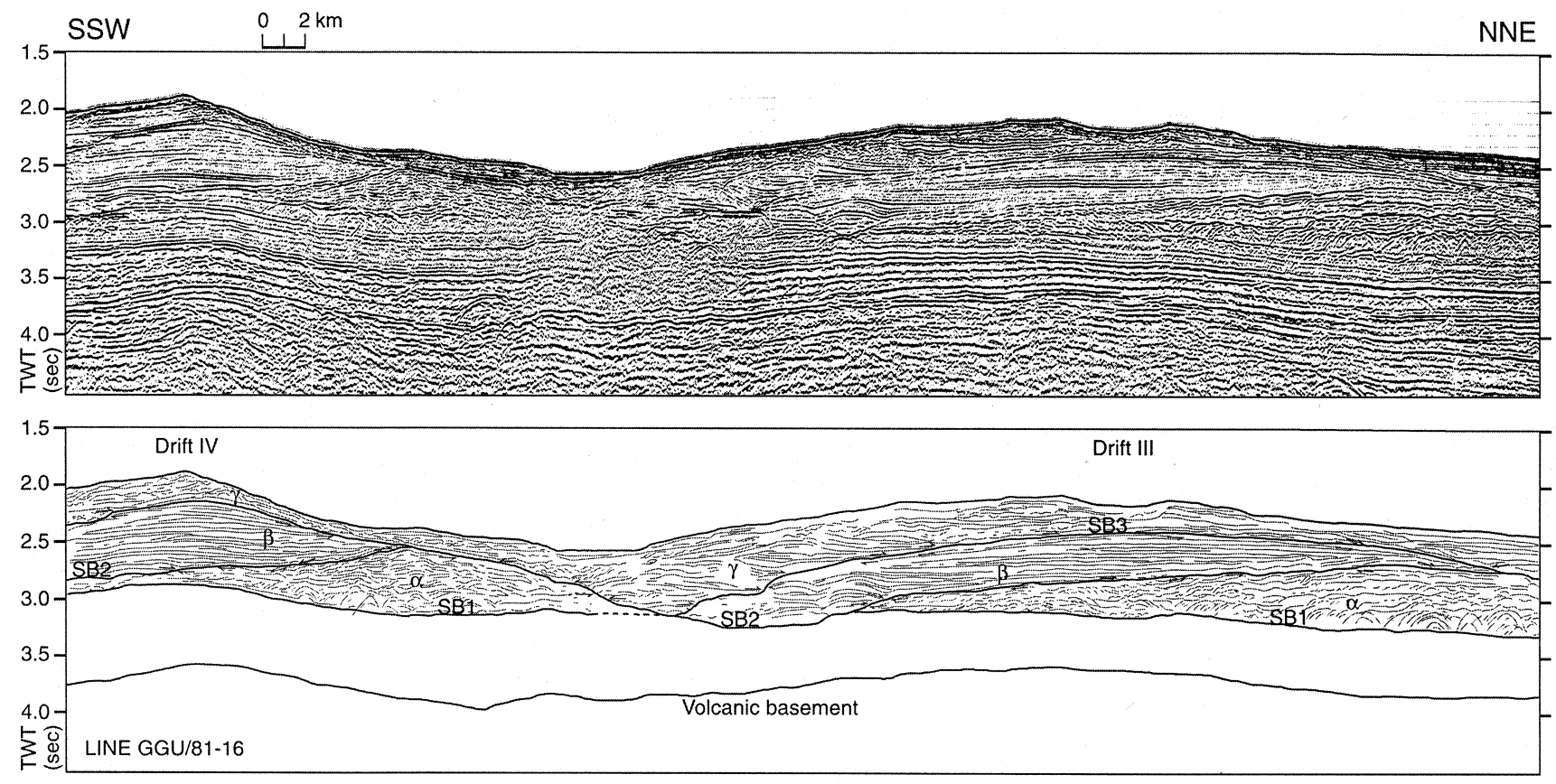

Figure 5. Deep seismic profile and interpreted line drawing illustrating the morphology and internal architecture of the elongate drifts (for location see Fig. 2). This dip-profile shows drift III separated by a moat from the continental slope. The sequences $\alpha, \beta$, and $\gamma$ and their bounding unconformities SB1, SB2, and SB3 are outlined.

be the most important contributor (Dickson et al., 1990; Dickson and Brown, 1994). The presumed core of the overflow current is positioned at $1600-2200 \mathrm{~m}$ depth at $64^{\circ}-65^{\circ} \mathrm{N}$, and is characterized by mean current speeds just above $25 \mathrm{~cm} / \mathrm{s}$ (Fig. 6C). Two other highvelocity zones are located at the base of the continental slope at a depth of 800-1500 m (Dickson et al., 1990; Dickson and Brown, 1994), which corresponds to the level of the LSW.

\section{SEISMIC CHARACTERISTICS}

Three seismic sequences $(\alpha, \beta$, and $\gamma$, in ascending stratigraphical order) have been identified within the upper Neogene to Quaternary deep-sea sedimentary succession (Figs. 4, 5). Site 918 provides the age control and some information on sedimentary facies (Larsen, Saunders, Clift, et al., 1994). The seismic sequences are bounded by regional unconformities referred to as SB1, SB2, and SB3 (in ascending stratigraphical order). The youngest sequence is bounded by the seafloor. Seismic facies analysis, that is, the external form of the sequences and their internal reflection configuration (see also Mitchum et al., 1977), is used to interpret the environmental setting and the depositional processes involved in their formation.

The recognition of the lower and middle sequences $(\alpha$ and $\beta)$ and their boundaries (SB1 and SB2) are based mainly on the GGU/1981 deep seismic profiles (Fig. 2). The analysis of the upper sequence $(\gamma)$ is based mainly on the GGU/1992 and 1993 high resolution seismic profiles (Fig. 2). All three sequences are characterized by external mound forms (sensu Mitchum et al., 1977) that make up the elongate drifts, but show different internal reflection configuration. Only Sequence $\gamma$ forms a continuous unit throughout the study area.

\section{Seismic Sequence $\alpha$}

This sequence has been recognized only within elongate drifts III-V seaward of the shelfal embayment, and it is best studied in drift III and IV. The lower boundary (SB1) is characterized by erosional truncation of underlying strata. Sequence $\alpha$ onlaps SB1 toward the continental slope and downlaps basinward. SB1 is truncated by SB2 between elongate drifts II and III and by SB3 between elongate drifts III and IV.

Seismic Sequence $\alpha$ displays an external mound form symmetric in cross section (Fig. 4). The unit makes up the nucleus of the elongate drifts, and is as much as $550 \mathrm{~m}$ thick, $30-40 \mathrm{~km}$ across, and 60 $\mathrm{km}$ long. The sequence has a semichaotic internal reflection configuration with abundant diffractions (Fig. 7E). Three to four subunits can be identified within the sequence separated by internal discontinuities characterized by high-amplitude hyperbolic diffractions (Fig. 7E). These diffractions seem similar on crossing seismic profiles suggesting a complex, 3-D origin. The semichaotic facies may laterally pass into a mounded-chaotic facies pattern (sensu Myers and Piper, 1988) (Fig. 7D). Semicontinuous reflections are also developed toward the top of Sequence $\alpha$ (Fig. 4).

\section{Seismic Sequence $\beta$}

This sequence is present in drifts II-V. Sequence $\beta$ is truncated by the succeeding unconformity SB3 between drifts III and IV. Sequence $\beta$ shows both onlap and downlap relations onto the basal unconformity SB2.

Externally, the sequence displays an asymmetric mound form, both in cross section (Fig. 4) as well as longitudinally (Fig. 5). The mounded parts of sequence $\beta$ are as much as $450 \mathrm{~m}$ thick, about 35 $\mathrm{km}$ wide, and probably more than $60 \mathrm{~km}$ long. The sequence drapes the southwestern flanks of sequence $\alpha$, and thins considerably across its crest (Fig. 4). Thus the position of the crests shifted about 10-15 $\mathrm{km}$ southward from unit $\alpha$ to $\beta$. Internally the sequence is characterized by a mounded-stratified seismic reflection configuration (sensu Myers and Piper, 1988), where low to moderate amplitude subparallel reflections converge westward (i.e., toward the continental slope) and toward the northeastern flank of the elongate drifts (Figs. 4, 5, $7 \mathrm{~A}, \mathrm{C})$. On the southwestern flanks of the elongate drifts the mounded-stratified facies pass into migrating-wave seismic reflection configuration (sensu Mitchum et al., 1977), showing a wavelength of about $2.5 \mathrm{~km}$ and an amplitude (crest-to-trough) of as much as $70 \mathrm{~m}$ 


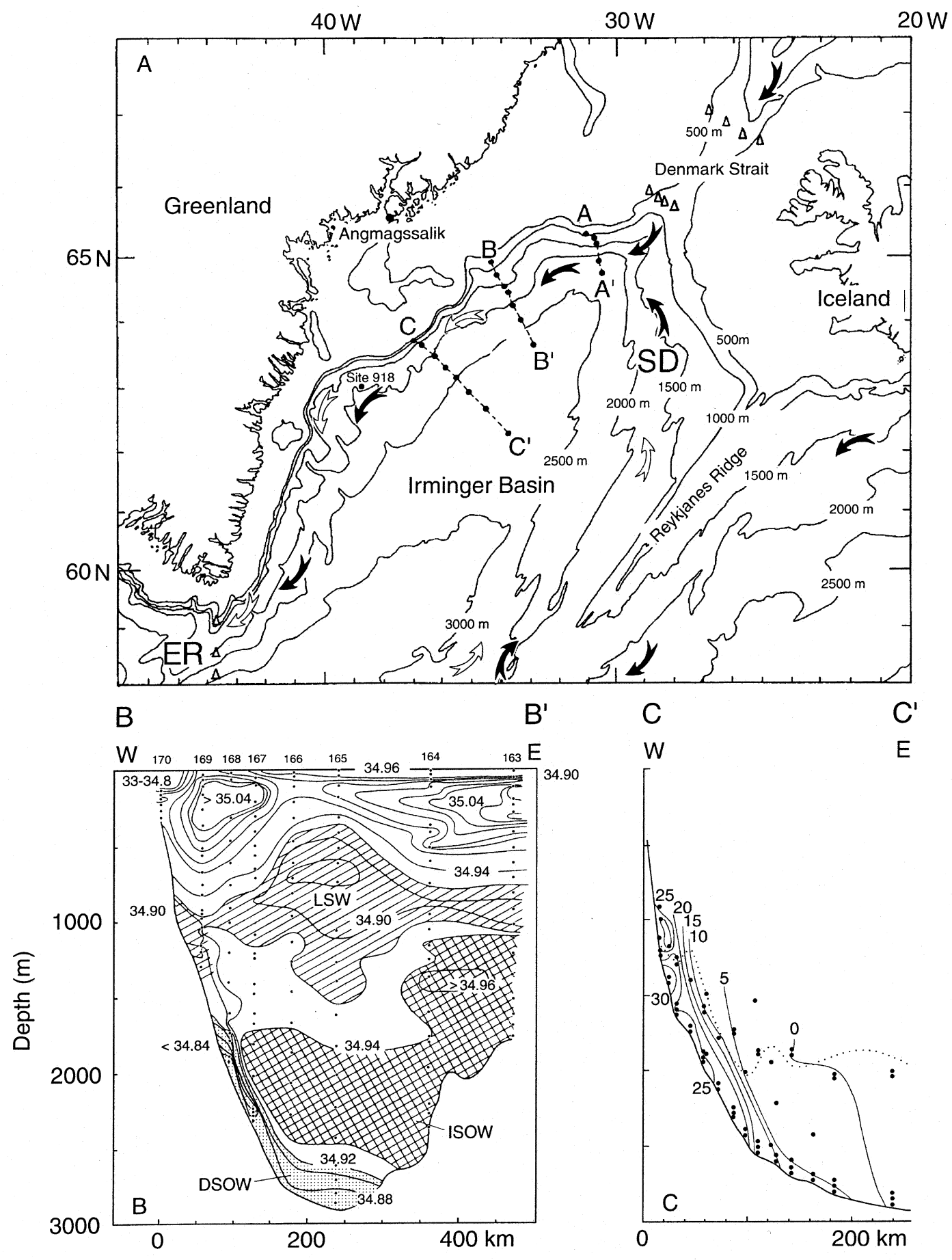

Figure 6. Pathways, sources, and rates of the North Atlantic Deep Water current (modified from Dickson and Brown, 1994). A. Proposed transport scheme for waters denser than $\sigma \theta=27$. Transects $\mathrm{A}-\mathrm{A}^{\prime}, \mathrm{B}-\mathrm{B}^{\prime}$, and $\mathrm{C}-\mathrm{C}^{\prime}$ are long-term current meter arrays; two are shown in (B) and (C). Solid arrows indicate the pathway of the Denmark Strait Overflow Water (DSOW) and the Iceland Scotland Overflow Water (ISOW), and open arrows the Labrador Sea Water (LSW) (1 Sv $=1 \times 10^{6} \mathrm{~m}^{3} / \mathrm{s}$ ). Site 918, the Eirik Ridge (ER), and the Snorri Drift (SD) are indicated. B. The vertical mass structure of the main water bodies in the North Atlantic Deep Water current (NADW) of the Irminger Basin in transect B-B'. The dense, cold Denmark Strait Overflow Water (DSOW) floors the deep sea Imassuak Channel and the continental rise of southeast Greenland. The DSOW is overlain by the Iceland Scotland Overflow Water (ISOW), which in turn is capped by the relatively fresh Labrador Sea Water (LSW). The LSW is located at the base of the southeast Greenland continental slope at a depth of 800-1500 $\mathrm{m}$. C. Distribution of mean velocities $(\mathrm{cm} / \mathrm{s})$ of the deep sea currents in the western Irminger Basin in transect C-C', combined with other data (see Dickson and Brown, 1994). The highest velocity current zones comprise mainly the LSW (open arrows of Fig. 6A), and the presumed core of the DSOW overflow (solid arrows of Fig. 6A). The $\sigma \theta=27.8$ isopycnal (dotted line) represents the minimum density of the contributors to the NADW production. 

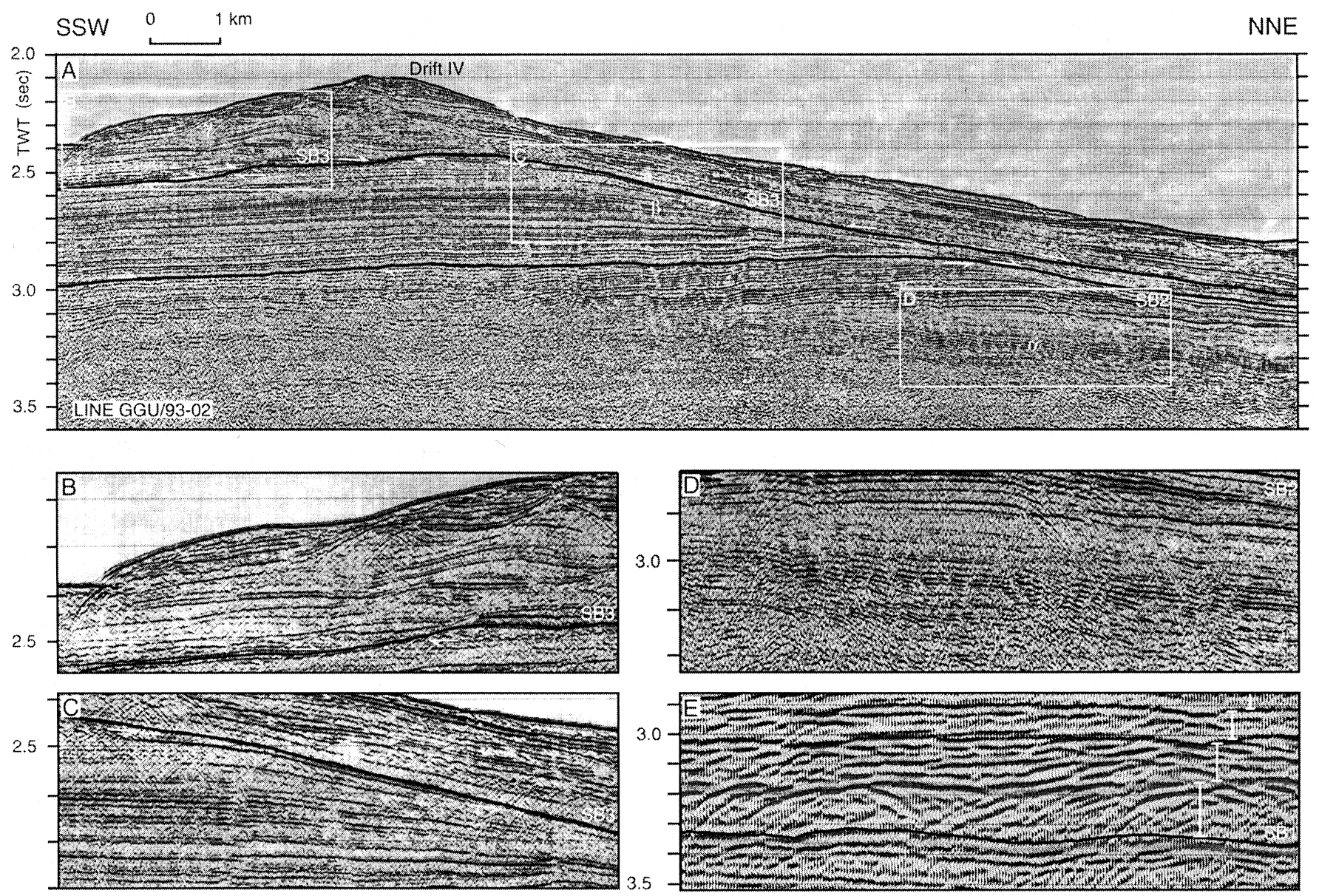

Figure 7. A. High resolution seismic profile shows seismic facies configurations of elongate drift IV (for location see Fig. 2). White frames indicate location of enlargement 7B-7D. B. Seismic Sequence $\gamma$ is characterized by upslope migrating seismic-wave reflection configuration (wavelength 1.5-3.5 km, height 10-40 $\mathrm{m}$, and apparent angle of climb $1.0^{\circ}-1.5^{\circ}$ ). C. Seismic Sequence $\beta$ is characterized by a mounded-stratified reflection configuration. Low to moderate amplitude subparallel reflections converge rapidly to the north and to the west. D. Seismic Sequence $\alpha$ is characterized by mounded-chaotic facies pattern. E. High-amplitude hyperbolic diffractions (details of Line GGU/81-16, Fig. 4). As much as four subunits are recognized within Sequence $\alpha$, indicated by white bars.

(Fig. 4). The mounded-stratified facies are locally characterized by a well-developed cyclic pattern (Fig. 7C), characterized by low amplitude, discontinuous reflections passing upward into high amplitude, continuous reflections. Each cycle is about 30-70 m thick. Adjacent to the continental slope the mounded-stratified facies contains a number of internal unconformities. Below the present-day moat there is generally a lack of reflectivity, but in places a buried moat correlated with Sequence $\beta$ can be identified on the basis of high amplitude concave-up reflections (Figs. 5, 8).

\section{Seismic Sequence $\gamma$}

This sequence has been recognized within all five drifts. The lower boundary (SB3) locally truncates both SB1 and SB2 between the elongate drifts. Erosion decreases basinward and seems to be most pronounced adjacent to the continental slope. Externally, the sequence has a mound shape within the elongate drifts, and form trough and basin fill (sensu Mitchum et al., 1977) in the bathymetric lows between the elongate drifts. The mounded forms are as much as 460 $\mathrm{m}$ thick but typically thinner (100-300 m), approximately $30-40 \mathrm{~km}$ wide, and about $65 \mathrm{~km}$ long. They thin to $75-150 \mathrm{~m}$ on the northeastern flank of the elongate drifts across the crest of the underlying Sequence $\beta$, and the position of the crests shifted only $1-5 \mathrm{~km}$ southward from Sequence $\beta$ to Sequence $\gamma$.
The mound forms are characterized by migrating- and climbingwave seismic reflection configuration. Relatively steep waves are consistently developed on the southern and western flanks of the elongate drifts; this is reflected in wavy relief of the seafloor (Fig. 7B). The waves show a wavelength of $1.5-2 \mathrm{~km}$ and an amplitude of $10-40 \mathrm{~m}$ (crest-to-trough). They are generally asymmetric with a shorter, steeper limb facing upslope. The internal structure of the waves suggests that they migrated upslope at an angle of about $1.0^{\circ}-$ $1.5^{\circ}$ (Fig. 7B). The wave crests on the south flanks seems parallel with the elongate drifts (i.e., approximately perpendicular to the present-day contour-current flow). Flat, irregular waves can be recognized at the northern flanks and across the crests of the elongate drifts. These waves have a wavelength of as much as $3.5 \mathrm{~km}$ and are 10-40 m high; reflections offlap in a northward direction and onlap in a southward direction suggesting an upslope direction of migration. Locally the wave facies passes into a subparallel reflection configuration or into acoustically almost transparent facies. Internal unconformities are abundant throughout the mounded form of Sequence $\gamma$.

Sequence $\gamma$ thins westward toward the base of the continental slope, where the present-day moats are located. In some places the moat truncates the reflections of the mounded form (Fig. 9), in other places the reflections converge toward the moat (Fig. 8). There is generally a lack of seismic reflectivity below the present-day moats, 

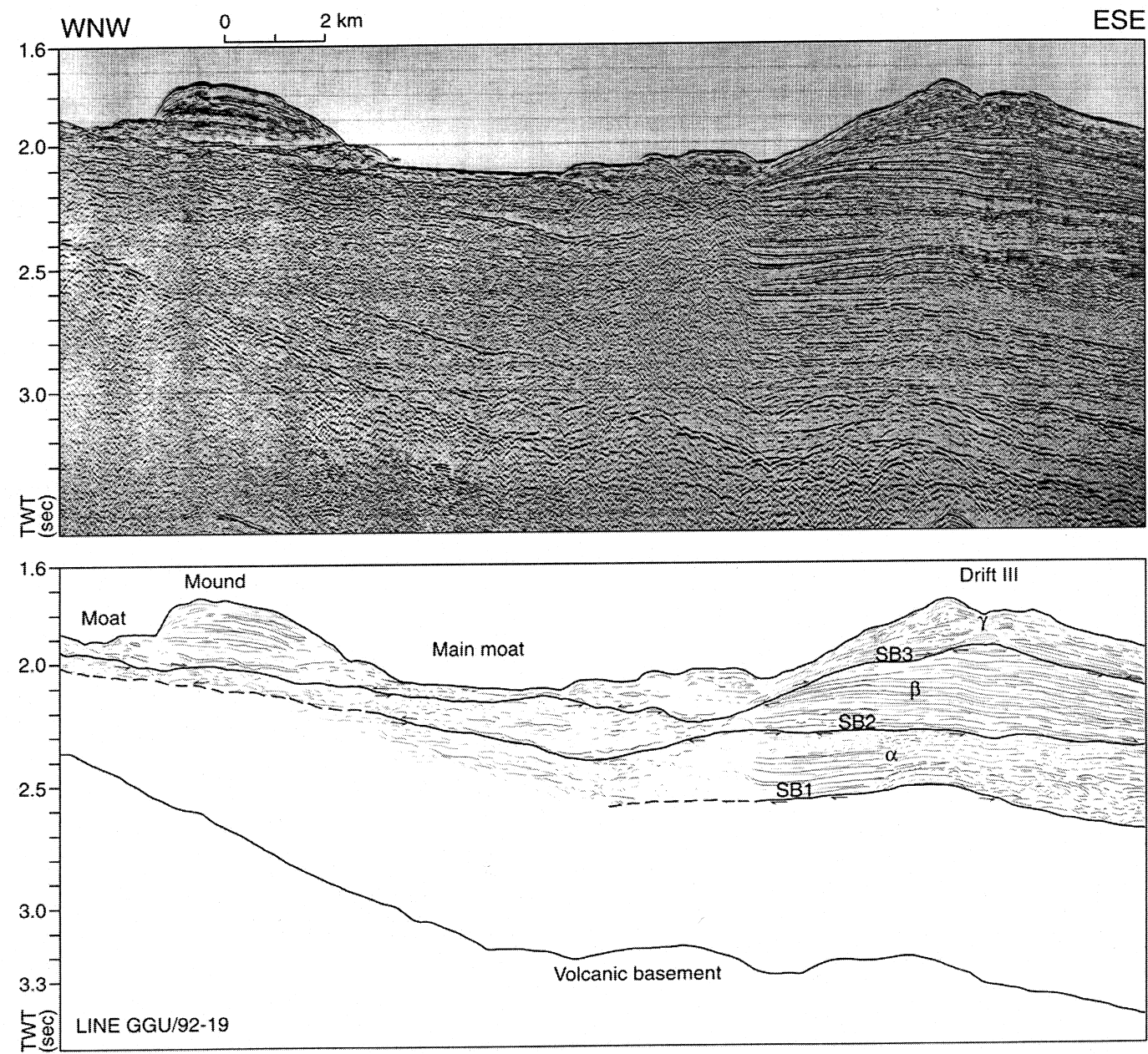

Figure 8. High resolution seismic profile and interpreted line drawing across the moat zone (for location see Fig. 2). The main moat is developed as a shallow depression. High-amplitude reflections below the modern moat are interpreted as buried moats. An elongate drift is developed seaward of the main moat, and shows three mounded seismic sequences $(\alpha, \beta$, and $\gamma$ ). A large mound and a smaller moat are located toward the continental slope. The elongate mound parallels the slope and exhibits an asymmetric cross section similar to that of the elongate drifts.

and in many places the lower sequence boundary cannot be identified; however, locally high amplitude and convex-up reflections can be discerned within the sequence (Fig. 8).

Within the moat zone the upper boundary of seismic Sequence $\gamma$, that is, the seafloor, defines recent mound structures. The mounds display a wide range of sizes and geometries, but are tentatively subdivided into two types: small mounds displaying a relatively simple internal structure with parallel and subparallel reflections, and with a base in level with the surrounding present-day seafloor (Fig. 10A); and large mounds extending down to several hundreds of meters below the modern seafloor, and displaying a migrating-wave seismic reflection configuration, where the upslope limb is the thickest (Fig. 10B). The base of the larger mounds, however, is poorly defined. In general all mounds are acoustically well layered, and characterized by parallel, semicontinuous to continuous reflections of low to medium amplitude. Some mounds, though, display an irregular relief formed by erosional features, $150-200 \mathrm{~m}$ deep. The associated diffractions obscure the reflection seismic image of the internal structure of these mounds (Fig. 10B).

The seismic reflection configuration of Sequence $\gamma$ changes from migrating-wave seismic reflection configuration within the elongate drifts to subparallel and parallel reflection configuration within the trough or basin fill between the drifts. Buried troughs, about 10-15 $\mathrm{km}$ wide, are present within Sequence $\gamma$ north of drifts III and IV; these are located beneath the present-day major channels exposed on the seafloor (Fig. 11). The fill of the basin southwest of drift II contains numerous buried subsidiary channels, which are located beneath or adjacent to the channels exposed on the seafloor (Fig. 12). There is evidence of lateral channel migration, generally toward the northeast, but abandoned channels with channel plugs have also been identified. The associated levées appear acoustically well layered and consist of regular, semicontinuous, parallel reflections of medium to high amplitude (Figs. 11, 12). Both recent and buried levées are characterized by numerous internal unconformities.

\section{INTERPRETATION OF SEISMIC SEQUENCES}

Interpretation of the seismic facies follows the work of Mitchum et al. (1977) and Myers and Piper (1988). Correlation can be made to Site 918 (see below) penetrating Sequences $\gamma$ (channel-levée complex) and $\beta$. The drill site is situated between two drifts, and thus the internal reflection configuration of the drifts cannot be compared with the borehole data. Site 919 is situated in the seaward end of the study area and penetrated $147 \mathrm{~m}$ of Sequence $\gamma$. The seismic data quality decreases downward, so the youngest Sequence $\gamma$ is the best 

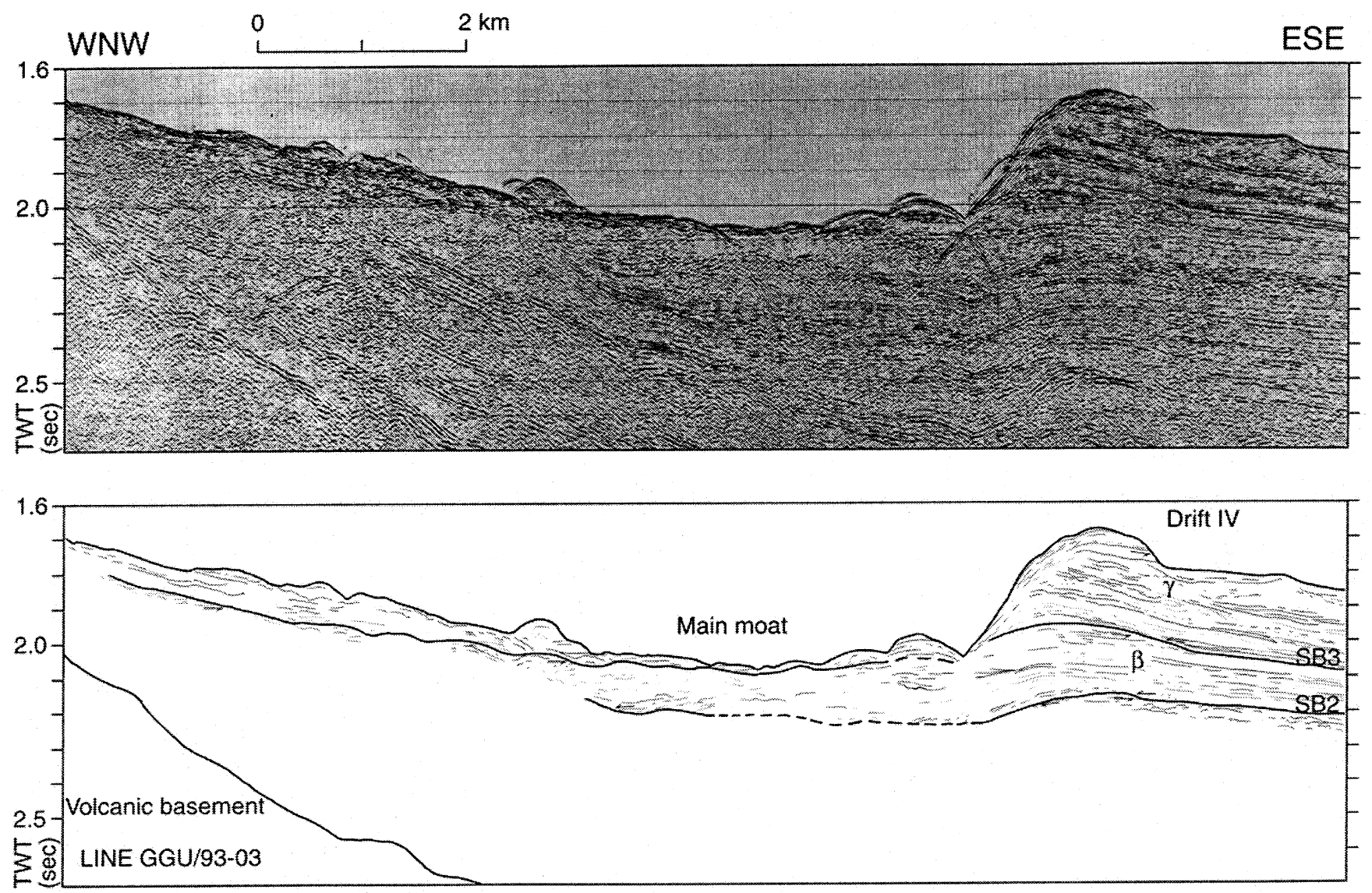

Figure 9. High resolution seismic profile and interpreted line drawing across the moat zone (for location see Fig. 2).The main moat displays deep erosion, and associated mounds are rather small. Their internal structure is obscured by hyperbolic diffraction.

surveyed unit. Hence the interpretations of Sequence $\gamma$ to some extent have been used as a template to infer the sedimentary processes involved in forming the two underlying sequences. For this reason the sequences are dealt with in descending order.

Sequence $\gamma$, draping the elongate drifts and infilling the interjacent basins, is interpreted to have been deposited mainly by turbidity and contour-current processes.

The trough and basin fill between the elongate drifts is interpreted as aggrading channel-levée complexes. The downslope orientation of the modern and buried channels is a clear indication of a turbidity current origin. The troughs are interpreted as buried valleys. The location of the buried valleys and the overlying present-day major channels suggest that the turbidity currents were sourced from the trough-mouth fans, probably by debris flows and/or other mass flows. The north-south trending buried subsidiary channels were probably tributaries to the neighboring major turbidity channel to the south. The levées, including the buried ones, are characterized by numerous internal unconformities, suggesting a repeated course of events with overbank deposition and intermittent erosion, which is characteristic for turbidity currents. The general tendency of lateral channel migration toward the northeast may be explained by the preferential deposition on the western levées, as observed in the modern levées. The asymmetry is most likely due to the effect from the Coriolis force on the turbidity currents, but contour-currents may also have contributed.

The moated area with mounds belonging to Sequence $\gamma$ is the clearest indication of contour-current activity on the continental rise. The complex zone, $15-25 \mathrm{~km}$ wide, reflects the lateral shifts of the high-velocity core of the current, and/or branching of the current into several distinct flows, separating areas of preferential and reduced deposition and/or erosion. The high-amplitude, convex-up reflections below the main moat (Fig. 8) are interpreted as channel lags, probably consisting of sand or gravel, within buried moats. The buried moat can be traced landward into mound deposits. The latter are suggested to represent moat-related drifts deposited from contourcurrents. The internal structure of the large, complex mounds suggests that they consist of fields of aggrading and upslope migrating mounds and/or sediment waves (Fig. 10B). Toward the continental slope some mounds are dissected by gullies or furrows. It is not possible to determine the orientation of these, and therefore it remains unclear whether downslope or alongslope processes are involved in their formation (Fig. 10B). Seaward the mounds pass gradually into the levées flanking the channels.

Sequence $\gamma$ also drapes the elongate drifts. The migrating-wave seismic reflection configuration of the sequence is interpreted as upslope migrating sediment waves. Such waves, however, are not diagnostic of contourites as they can also be formed by turbidity currents. For instance, they have been observed on the backside of levées bounding deep-sea fan channels (Hamilton, 1967; Damuth, 1975; Hess and Normark, 1976; Normark et al., 1980). In these cases, however, a contour-current origin cannot entirely be ruled out. No criteria have so far been outlined to serve the distinction between turbidityand contour-current-generated sediment waves other than their location (on levées or drifts). As both contour-currents and turbidity currents appear to have been involved in the formation of the mounded forms of Sequences $\gamma$ and $\beta$ (see below), it cannot be excluded that the steep sediment waves of the south flanks were generated by turbidity currents, but a contour-current origin is considered more like- 
A
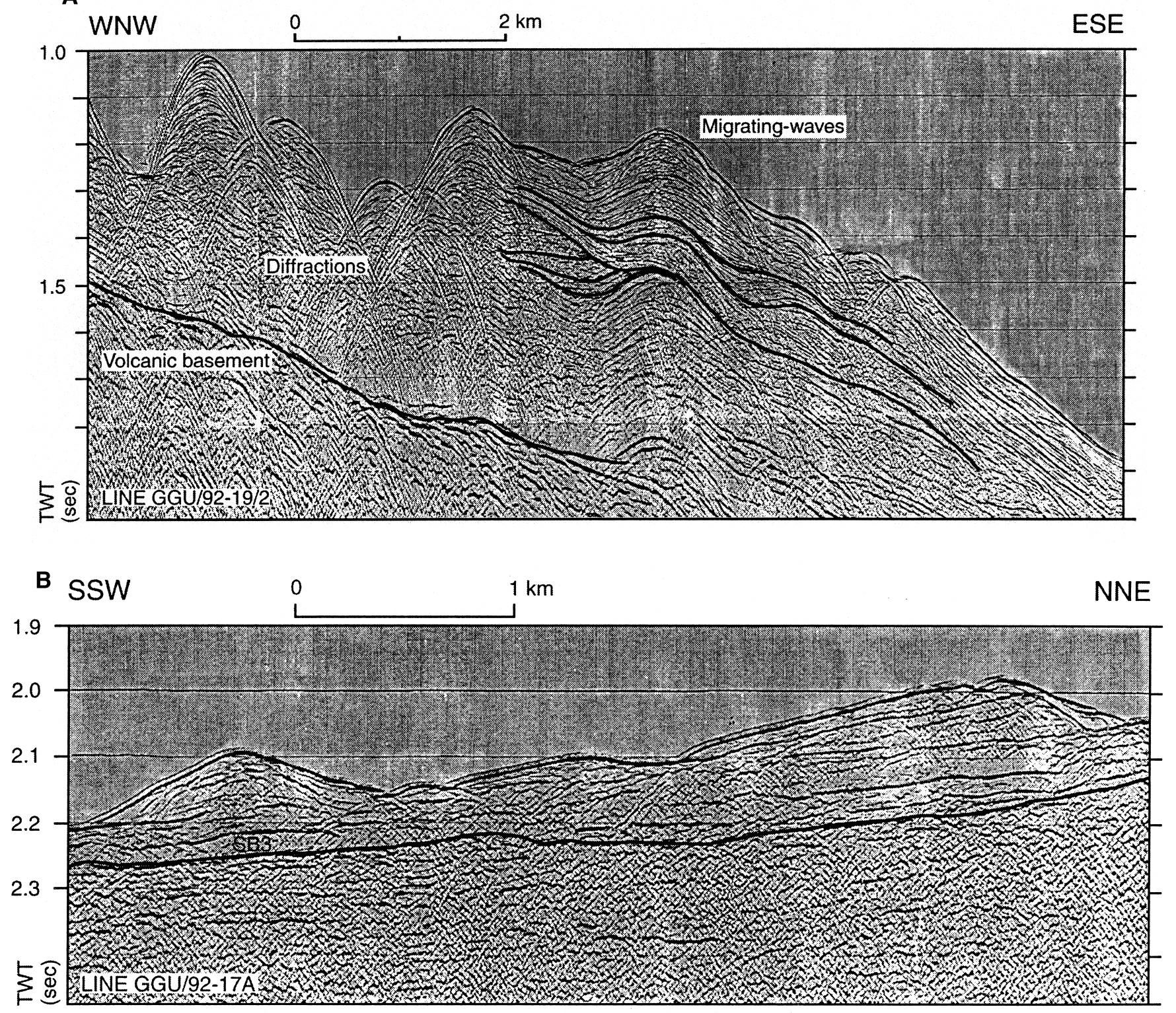

Figure 10. High resolution seismic profiles across the moat zone (for locations see Fig. 2). A. Small acoustically well layered mounds exhibiting symmetric and asymmetric cross sections. B. Comparatively large mound displaying an internal structure of aggrading and upslope migrating seismic-wave reflection configuration. Numerous internal unconformities occur, and the upslope part of the mound is dissected by 150-200 m deep erosional features. Hyperbolic diffractions obscure the reflection seismic image of the internal structure.

ly, because they are similar to sediment waves developed on the western side adjacent to the moat, where contour-current processes govern. The internal structure of the low-amplitude waves located on the northern flank of the mounded forms suggests that they also migrated upslope and, opposed to the steep sediment waves, thus migrated in the flow direction of the contour-current. It is likely that a major part of the sediment deposited on the southern flank of the drifts, the lee side, originated from the main turbidity channels and bypassed the northern flanks as low-amplitude sediment waves.

There is no drill core information from the mounded forms within the elongate drifts, but seismic Sequence $\gamma$ correlates with the turbidite successions of lithologic Subunits IA and IB at Site 918 (Larsen, Saunders, Clift, et al., 1994). Apart from large ice-rafted clasts the sedimentary record is here dominated by silt and clay, hence the drift of Sequence $\gamma$ most likely consists of silt or finer grained sediment, if the turbidites are the main sediment source as inferred (see also "Discussion and Conclusions" section).

SB3 separating Sequence $\gamma$ from the underlying Sequence $\beta$ marks a major change in the depositional environment. The seismic reflection configuration characterizing the mounded form of Sequence $\gamma$ is more complex compared to the relatively simple mounded-stratified facies below. This may reflect an upward shift from comparatively uniform to more fluctuating depositional conditions.

The seismic reflection configuration and the asymmetric mounded outer geometry of seismic Sequence $\beta$ indicate that there were two main directions of sediment supply to the drifts; from the west (along the base of the continental slope) and from the north (along major turbidity channels). The convergence of the seismic reflections toward the present-day moat and below the buried valley suggest sediment bypass across the western and the northern side of the drifts and pref- 

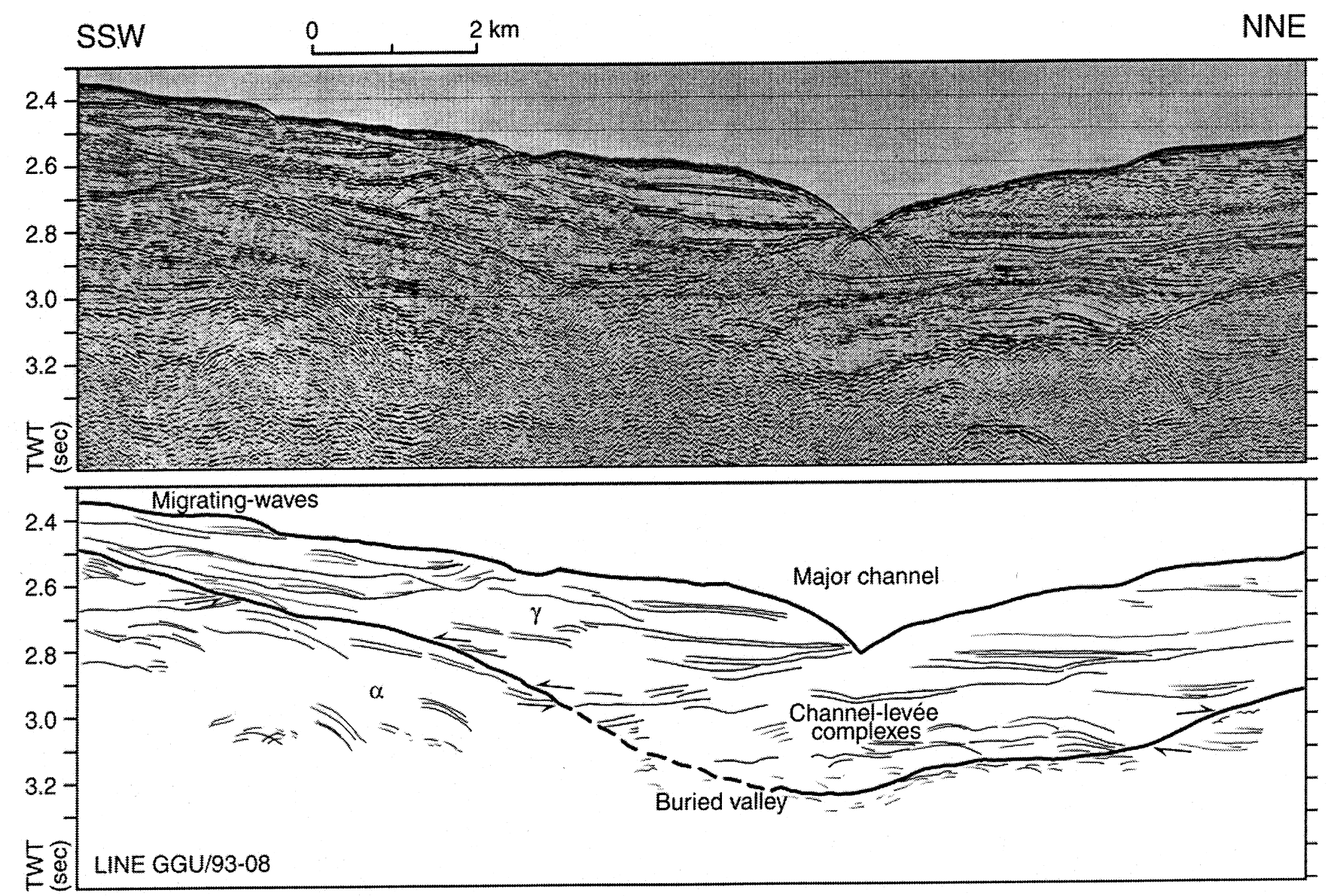

Figure 11. High resolution seismic profile and interpreted line drawing across channel-levée complexes (for location see Fig. 2) showing a buried valley, approximately $10 \mathrm{~km}$ wide, developed beneath a modern turbidity channel, and filled in by channel-levée deposits.
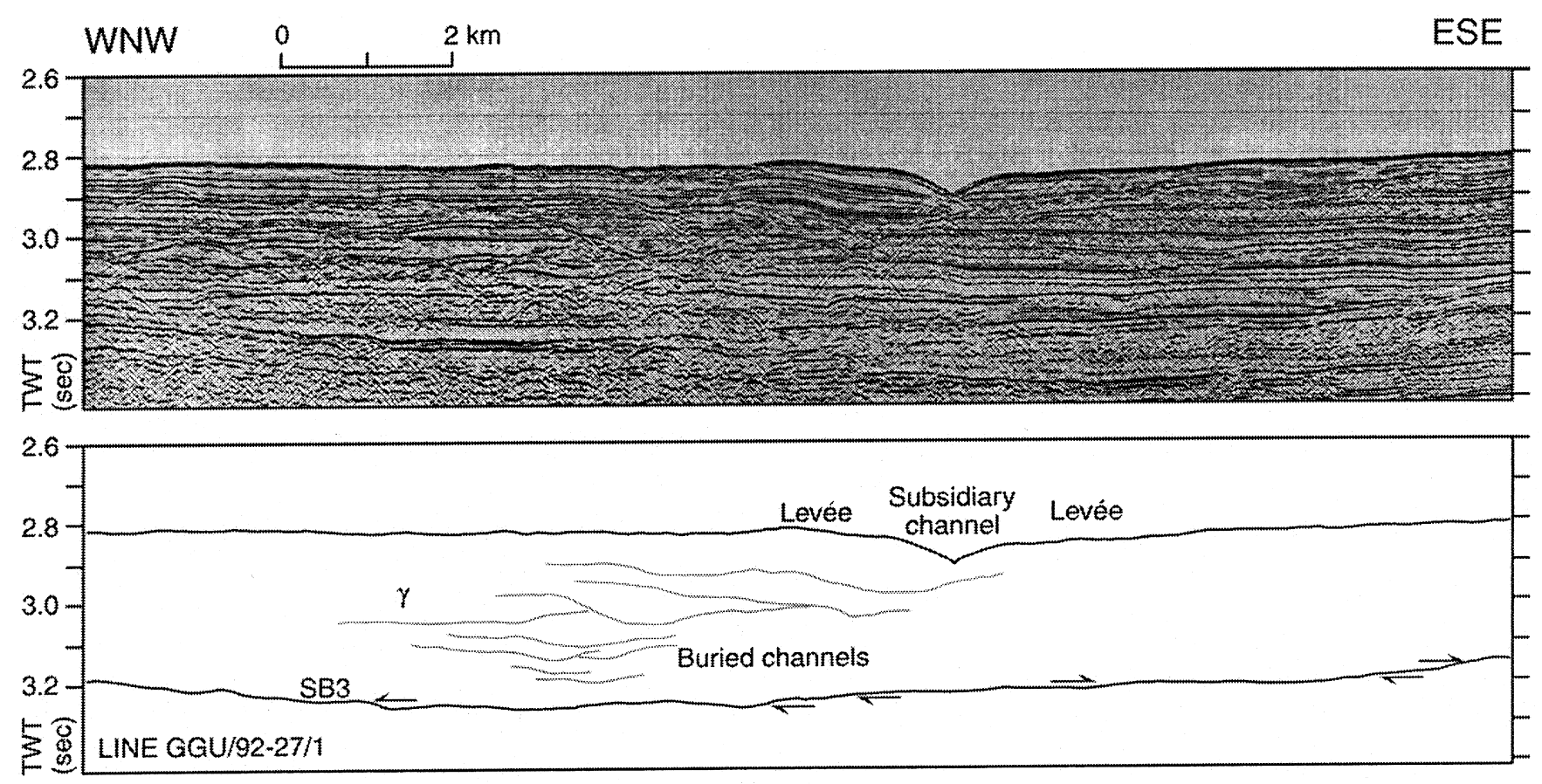

Figure 12. High resolution seismic profile and interpreted line drawing across channel-levée complexes (for location see Fig. 2) showing lateral migration of buried channels located beneath a modern turbidity channel. 
erential deposition on the eastern and southern sides. The indications of a buried moat near the continental slope within Sequence $\beta$ agree well with deposition from a southward-flowing contour-current in the more tranquil zones eastward of the high-velocity core of the current. It is considered likely that the turbidity channels, each acting as a northern line-source, were present along the northern flanks of the drifts, but they are not preserved in the record. The base of the buried valley (SB3) may thus represent a time gap during which turbidites were reworked by contour-currents and redeposited on the elongate drifts and/or by turbidity currents with deposition farther downslope as sheet deposits. This inference is based on comparison with Sequence $\gamma$ (q.v.). It is not yet clear whether both sediment sources acted simultaneously during deposition of Sequence $\beta$, and it is still uncertain how the mounded-stratified and the cyclic seismic pattern should be interpreted. The seismic reflections may signal either a variation (occasional cyclic) in the sediment character (composition/structure/ texture), in the turbidity current processes or in the intensity of the contour-current. The internal unconformities that characterize the westward end of the contourite drift may reflect variation in the position and/or width of the high-velocity core of the contour-current. The migrating-wave seismic reflection configuration is interpreted as sediment waves formed on the lee-side of the drift by a southward flowing contour-current (compare Sequence $\gamma$ ).

Seismic Sequence $\alpha$ makes up the nucleus of the elongate drifts, but it is not believed deposited by contour-currents. The diffractions characterizing the top of each subunit within the sequence may have been produced by either small faults related to slumping, or channels or flutes causing the reflections to be disrupted (Fig. 7E). A similar seismic pattern, interpreted as current-controlled deposition (contourites), has been observed beneath the continental slope off eastern United States and at the Blake Outer Ridge (Mountain and Tucholke, 1985). However, the symmetric external shape of Sequence $\alpha$ and the location right in front of the trough-mouth fans points to a more likely origin as basin floor fans rather than a result of contour-controlled deposition.

\section{DRIFT STRATIGRAPHY AND CORRELATION}

Two of the seismic sequences ( $\beta$ and $\gamma$ ) are correlated with ODP Site 918 (Fig. 13) using the two-way traveltime vs. depth relationship established for Site 918 (Larsen, Saunders, Clift, et al., 1994). SB3, which is of middle Pliocene age, is located at approximately $300 \mathrm{~m}$ depth. It is positioned immediately above the base of lithologic Subunit IC of Site 918 that marks a significant increase in the sedimentation rate. SB2, which is of early Pliocene age, is located at approximately $470 \mathrm{~m}$ depth. The sequence boundary corresponds to a level somewhat above the first occurrence of dropstones (Larsen, Saunders, Clift, et al., 1994). SB1 is truncated by SB2 short southwest of the drill site. Hence seismic Sequence $\alpha$ is not present at the drill site and an age can only be indirectly estimated. SB1 overlies, however, an unconformity that in Site 918 is located at the transition between the middle and upper Miocene. Thus SB1 is dated between the middle/late Miocene boundary and the early Pliocene, and consequently postdates the level taken to represent the onset of the NADW, based on the first appearance of NADW affiliated benthic foraminifers as well as a number of glauconitic/micritic hardgrounds, each overlain by coarse poorly sorted sand (Larsen, Saunders, Clift, et al., 1994).

A tentative correlation of the seismic sequences and bounding unconformities to other parts of the North Atlantic region is outlined in Table 1 . The correlation is based mainly on seismic facies configurations of the sequences, the approximate ages of the bounding surfaces, and interpretations of the depositional and erosional processes involved.

SB3 apparently correlates well with the "blue reflector" recognized along the U.S. Atlantic continental margin, and which is suggested to represent a pulse of erosion by bottom-currents (Mountain

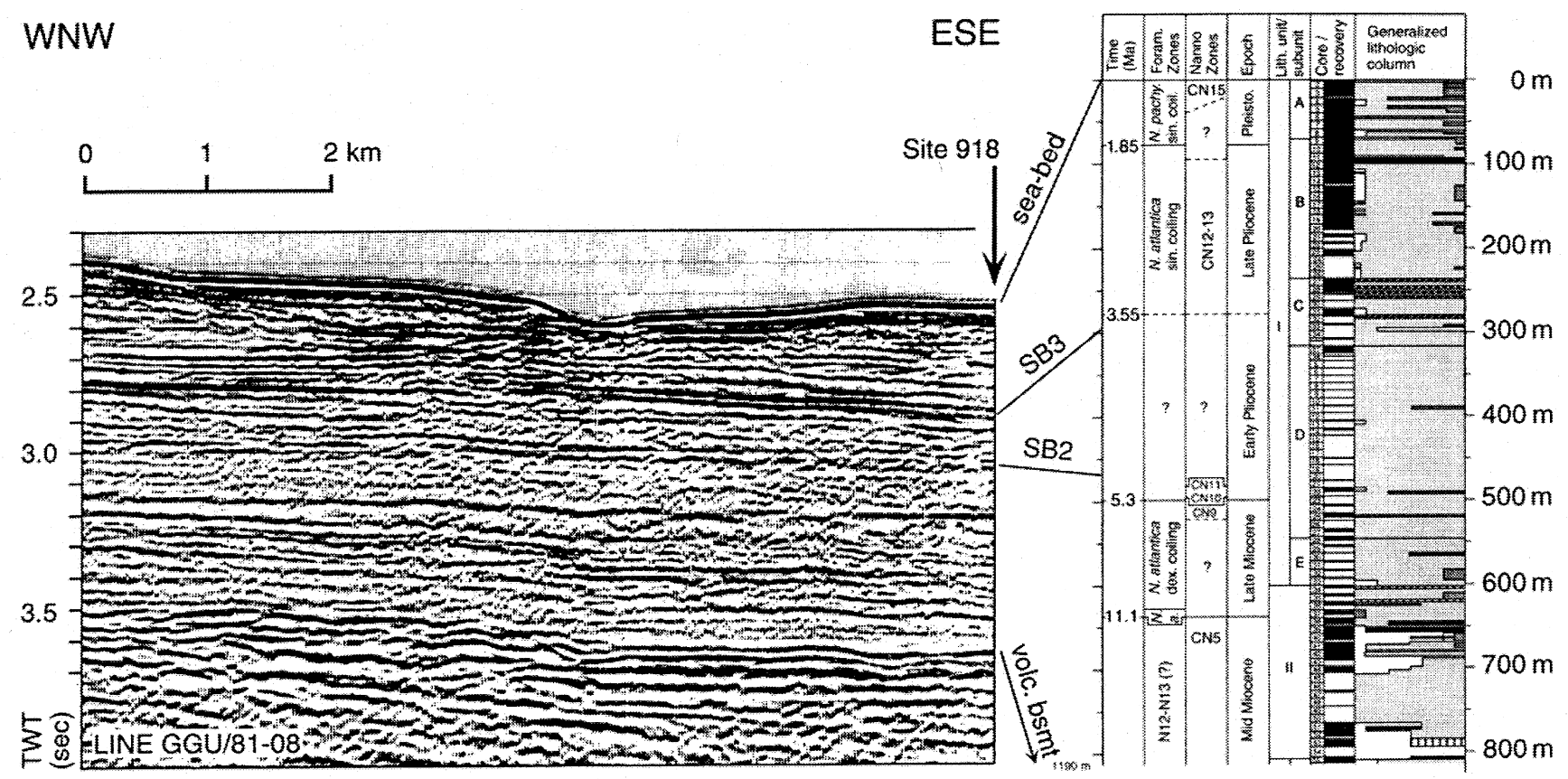

Figure 13. Deep seismic profile showing correlation of SB2 and SB3 with ODP Site 918 (Larsen, Saunders, Clift, et al., 1994). SB1 is truncated by SB2 southwest of Site 918. SB2 and SB3 are of early Pliocene and middle Pliocene ages. The dashed line indicates an unnamed unconformity older than SB1 at the transition between the middle and upper Miocene. The geological time scale is adopted from Cande and Kent (1992) and the litho- and biostratigraphy are adopted from Larsen, Saunders, Clift, et al., 1994. For lithology legend see Larsen, Saunders, Clift, et al., 1994, Chapter 10, fig. 6. 
Table 1. The approximate ages of seismic reflections and unconformities recognized within the North Atlantic by various authors.

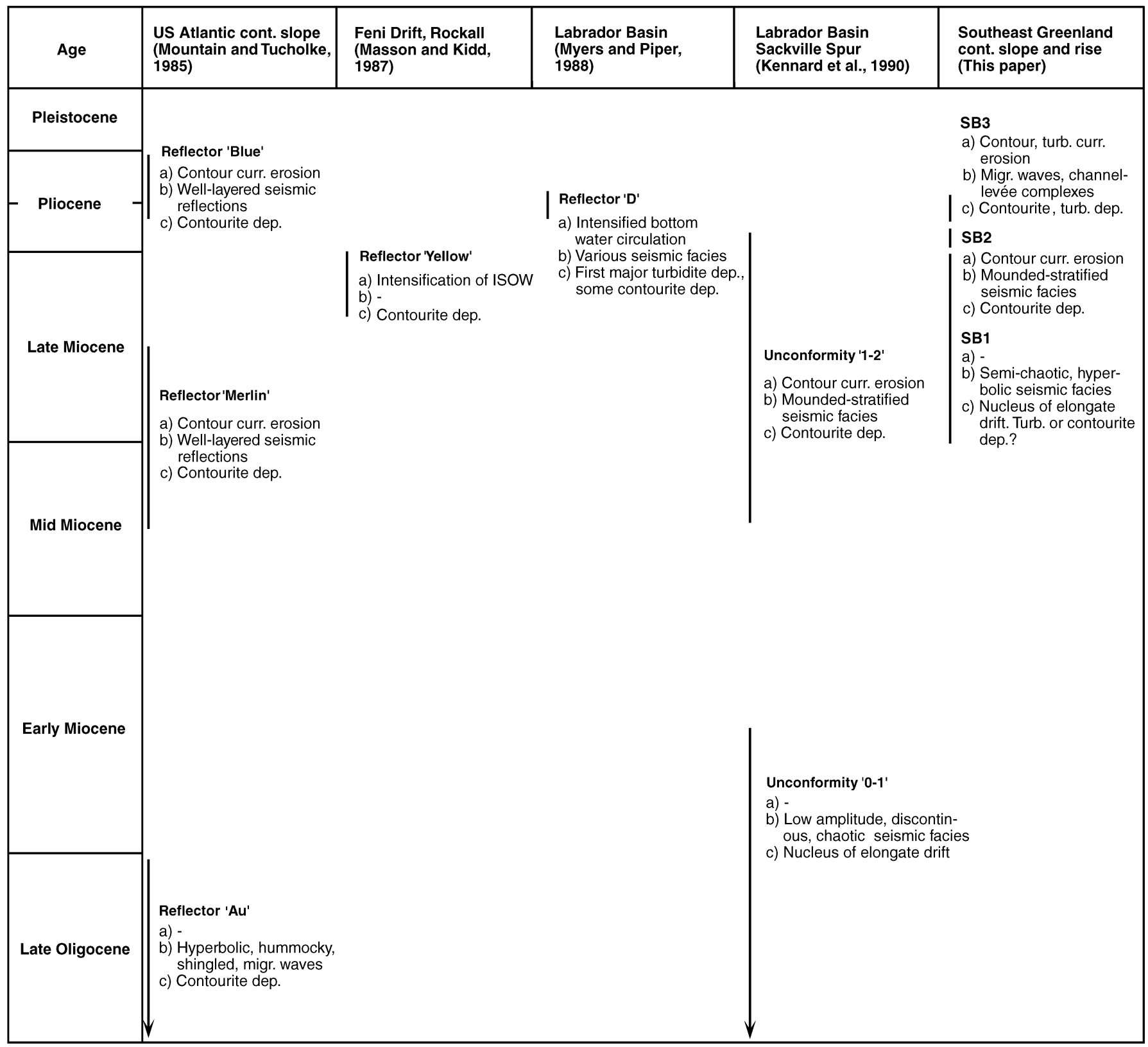

Notes: The information listed includes: a) interpretation of seismic reflection, b) seismic character of the overlying unit, and c) interpretation of the overlying unit. Abbreviations used: curr. $=$ current, dep. $=$ deposition, migr. $=$ migrating, ISOW $=$ Iceland-Scotland Overflow Water, turb. $=$ turbidite .

and Tucholke, 1985). In the Labrador Basin, Myers and Piper (1988) identified a seismic "reflector D" of middle Pliocene age, inferred to reflect intensified bottom-water circulation, and which they correlated with the "blue reflector" of Mountain and Tucholke (1985). The seismic facies above "reflector D" were interpreted as reflecting the first major turbidite deposition. This is analogous to the channellevée complexes developed above the SB3 in the western Irminger Basin, and the age also matches as far as can be established. Core data from the Snorri Drift in the northeastern Irminger Basin (Fig. 6), located below the inferred northward-flowing limb of the Iceland Scotland Overflow Water, ISOW (DSDP Sites 407 and 408), also reveal a major hiatus, probably reflecting erosion by contour-currents, and separating lower Pliocene and upper Miocene sediments from Pleistocene turbidites (Shor and Poore, 1979).
SB2 is roughly coeval with the "yellow reflector" observed on the Feni Drift in the Rockall Trough by Masson and Kidd (1987). They suggested that the "yellow reflector" represents intensification of the ISOW, and it was correlated with the "R1 reflector" of Miller and Tucholke (1983). The SB2 of the present study also seems to correlate with the "unconformity 1-2" of middle Miocene to early Pliocene age observed on the Sackville Spur in the Labrador Sea by Kennard et al. (1990). The "unconformity 1-2" was suggested to reflect erosion by the Labrador Current of an older drift beneath the spur (for details, see Thompson et al., 1986). Kennard et al. (1990) correlated the "1-2 unconformity" with the "Merlin reflector" described from the U.S. continental rise in the North Atlantic by Mountain and Tucholke (1985). The seismic "unit 2" above "unconformity 1-2" displays a mounded-stratified facies configuration suggested to reflect 
rapid drift buildup and progradation of the Sackville Spur to the northeast during late Miocene to Pleistocene times. Thus the seismic character of "unit 2" in the Labrador Sea corresponds well with that of Sequence $\beta$, representing a major drift phase within the western Irminger Basin.

Seismic Sequence $\alpha$ of the western Irminger Basin cannot immediately be correlated with other seismic units in the North Atlantic. However, the seismic "unit 1," recognized in the Sackville Spur, is characterized by low-amplitude, discontinuous, chaotic seismic facies succeeded by regular, parallel to subparallel reflections (Kennard et al., 1990). This seismic facies configuration is quite similar to that of Sequence $\alpha$. Both seismic units form the nucleus of elongate drifts, but seismic Sequence $\alpha$ was probably deposited by turbidity currents and other mass-flow processes forming a nuclei for later drift accumulation, whereas "unit 1" is inferred to be deposited by contour-currents (Kennard et al., 1990). The unconformity at the base of "unit 1" has been dated as late Eocene to early Miocene (Kennard et al., 1990) and thus pre-dates SB1. The younger age of SB1 suggests a rough correlation with the "Merlin reflector" of the U.S. Atlantic continental slope and rise of Mountain and Tucholke (1985). The "Merlin reflector" was, however, correlated with the "1-2 unconformity" by Kennard et al. (1990). Seismic Sequence $\alpha$ is also characterized by a seismic facies configuration somewhat similar to that observed in the seismic unit overlying the late Oligocene or older " $A_{u}$ reflector" and interpreted as contourites by Mountain and Tucholke (1985).

\section{DISCUSSION AND CONCLUSIONS}

The present seismic study of the southeast Greenland continental slope and rise shows that analogues to the existing surficial morphology, comprising elongate drift-moat and channel-levée complexes, are preserved also in the subsurface. The modern seafloor morphology in combination with seismic data therefore formed an integrated basis for interpretations of the late Neogene and Quaternary depositional environment.

No elongate drifts have been recognized north of $64^{\circ} 30^{\prime} \mathrm{N}$, but seismic data are admittedly scarce in that area. Judging from the available data, elongate drifts are best developed south of latitude $63^{\circ} \mathrm{N}$, seaward of the large southeast Greenland shelfal embayment, where the shelf is quite narrow and the continental slope is unusually steep (Fig. 3). This distribution of bathymetric features sparks a number of questions, addressed in the following discussion: (1) why is the continental slope so steep south of $64^{\circ} 30^{\prime},(2)$ why are elongate drifts present only south of $64^{\circ} 30^{\prime},(3)$ hence, are the steep slope and the development of drifts connected phenomena, (4) how does the significant change in shelf width influence the deep-sea depositional environment, and (5) why are the elongate drifts arranged perpendicular to the slope.

A steep continental slope may cause current intensification and velocity increase of deep contour-currents, according to McCave and Tucholke (1986), and the present-day contour-currents in the study area are quite strong (Fig. 6C). However, it is more likely, in this case, that the strong contour-current is the primary cause of the steep slope development. This inference is supported by the circumstance that the significant steepening of the continental slope south of latitude $65^{\circ} \mathrm{N}$ coincides with the rapid increase in deep-water transport assigned to the entrainment of the Labrador Sea Water (Fig. 6A). The depth stratum of the high-velocity core of the present-day LSW contour-current at $800-1500 \mathrm{~m}$ matches very well the position of the moat zone at a depth of $1000-1700 \mathrm{~m}$. It is envisaged that erosion takes place below the current core (i.e., steepening of the continental slope and formation of a moat zone) with associated deposition in the adjacent basinward, comparatively tranquil zone (i.e., formation of elongate drifts).
It is likely that further current intensification and velocity increase of the NADW was caused by the marked bend of the shelfal embayment/continental slope (cf. McCave and Tucholke, 1986), and which resulted in even stronger contour-current erosion with associated deposition of drifts on the continental rise.

In relation to questions $1-3$ posed above, it is concluded that strong, erosive contour-currents, the steepness of the slope, and the development of drifts are interrelated phenomena.

A further contribution to the concentration of drifts in the shelfal embayment could be the significant decrease of shelf width from 150 $\mathrm{km}$ to $50 \mathrm{~km}$, associated with an increase in the density of the shelf troughs. The narrow shelf accommodated less sediment during grounded ice events than the wider shelf to the north, and thus more sediment was transferred to the continental rise.

The rate and the nature of the sediment supply to the shelf edge and upper slope could be speculated also to have influenced the slope outline. It is evident from the bathymetry (Fig. 3) that the steepest slope segments are developed in front of the transverse shelf troughs, where the glacial sediment supply was highest. Further, the unsorted character of the glacial material delivered to the shelf edge (see Lykke-Andersen, this volume) and redeposited on the continental slope possibly allowed for a comparatively steep slope to develop. However, the nature and supply of the sediment appears of secondary importance in relation to the slope development, considering that the continental slope seaward off the more northerly situated Storfjord Shelf Trough is rather gently dipping (cf. Sommerhoff, 1979, fig. 2).

The distribution, morphology, and internal reflection configurations of the elongate drifts suggest that they are genetically associated with downslope processes. All elongate drifts, except one, are located immediately south of a major turbidity channel and are in a sense giant single levées, as suggested by the wing-shaped geometry (Figs. 4, 7A). The sediments, travelling down the turbidity channels, were affected by both the southward-flowing contour-current as well as the effect of the Coriolis force, resulting in deposition preferentially on the southern overbank. Thus the elongate trend of the drifts perpendicular to the direction of contour-current flow reflects this interference with downslope processes (cf. question 5 above). The location of the buried valleys and of the modern major turbidity channels in direct continuation of the shelf trough/trough-mouth fan system suggests that the downslope processes on the continental rise were regulated by the advance and retreat of the ice across the shelf (work is in progress to elucidate this aspect; it is relevant in the present context to emphasize that the positions of the shelf troughs were permanent throughout the late Neogene and Pleistocene). However, it is not possible solely on the basis of the seismic data to determine how the timing of deposition of the turbidites, or the contourites for that matter, specifically relates to the glacial cycles. The size of the drainage area during glaciations most likely also had some influence on the deepsea depositional environment, but also this issue is beyond the scope of the present paper.

The long-term history of the elongate drift development in the Irminger Basin includes two major phases of deposition (Sequences $\gamma$ and $\beta$ ). The drifts in the study area are comparatively young viewed in a North Atlantic context (Table 1), but match increased rates of drift deposition seen elsewhere in this region (cf. Miller and Tucholke, 1983). The onset of NADW in the Irminger Basin, however, is dated to the middle Miocene (Larsen, Saunders, Clift, et al., 1994), but apparently without associated local drift deposition. It is speculative which set of environmental conditions triggered the initiation of drift accumulation, but it is possible that drift deposition did not commence until the main turbidity channels on the continental rise were established. A plausible scenario is that these turbidity channels carried large amounts of sediment in suspension to the deep sea, where it was directly picked up by the contour-current and eventually deposited as elongate drifts. It is quite likely that the development of the turbidity channels was related to the enhanced sediment delivery to 
the shelf edge associated with glacial conditions on the shelf. This is also in accordance with their location in front of the trough-mouth fans, as mentioned above. It is, however, poorly understood why the older Sequence $\alpha$, interpreted as basin-floor fans, displays no obvious features indicative of contour-current deposition. But one possible explanation could be that the basin-floor fans were deposited primarily by unchannelized mass-flow processes, and that the contour-currents were incapable of reworking the sediment. Another explanation could be that major contour-current deposition did not take place until these fans created a sufficient seafloor relief providing a lee-effect favorable for drift accumulation.

There are many similarities between the South Greenland Eirik Ridge and the smaller sized elongated drifts described here. All are arranged perpendicular or with a very high angle to the continental slope; the elongate drifts are developed in a similar range of water depths; they are all separated from the upper, steep slope by a moated area, and flanked on the upstream side by a turbidity channel. In case of the Eirik Ridge, it is flanked by the Imassuak Channel (Egloff and Johnson, 1975; Myers and Piper, 1988). Sediment drifts and intermittent buried channels described by McGinnis and Hayes (1994) from the continental rise along the Antarctic Peninsula exhibit striking similarities to the drift-moat complexes and channel-levée complexes along the southeast Greenland margin. Turbidity processes might prove to be directly involved in the formation of drifts located off other (paleo-) glaciated margins as described from East Canada, Northwest Britain, and Antarctica (van der Linden et al., 1976; Kennard et al., 1990; Howe et al., 1994; Eittreim et al., 1995; McGinnis and Hayes, 1995). Hence mixed depositional systems as described from southeast Greenland might prove common or even typical for continental rises, swept by geostrophic deep-sea currents, off shelves characterized by shelf troughs and associated trough mouth fans.

\section{ACKNOWLEDGMENTS}

This work is part of a Ph.D study funded by the University of Copenhagen and supervised by S. Funder (Geological Museum, Univ. of Copenhagen) and H.C. Larsen (Danish Lithosphere Centre). The high resolution seismic surveys were funded by the Danish Natural Science Research Council, and the seismic data were processed by S. Berendt Marstal and H. Lykke-Andersen, Geological Institute, University of Aarhus. The seismic lines were made available by the Geological Survey of Greenland [now merged with the Geological Survey of Denmark]. Christian Marcussen (Geological Survey of Greenland) is thanked for technical support. Various aspects of the manuscript were discussed with S. Funder, L. Hansen, A. Thorshøj Nielsen (Geological Museum, Univ. of Copenhagen), J. Chalmers (Geological Survey of Greenland), and L.O. Boldreel and A. Kuijpers (Geological Survey of Denmark). The initial manuscript benefited from comments by M. Stoker, J.T. Andrews, and H.C. Larsen.

\section{REFERENCES}

Asquith, S.M., 1979. Nature and origin of the lower continental rise hills off the east coast of the United States. Mar. Geol., 32:165-190.

Cande, S.C., and Kent, D.V., 1992. A new geomagnetic polarity time scale for the Late Cretaceous and Cenozoic. J. Geophys. Res., 97:1391713951.

Damuth, J.E., 1975. Echo character of the western equatorial Atlantic floor and its relationship to the dispersal and distribution of terrigenous sediments. Mar. Geol., 18:17-45.

Dickson, R.R., and Brown, J., 1994. The production of North Atlantic Deep Water: sources, rates, and pathways. J. Geophys. Res., 99:12319-12341.

Dickson, R.R., Gmitrowicz, E.M., and Watson, A.J., 1990. Deep water renewal in the northern North Atlantic. Nature, 344:848-850.

Egloff, J., and Johnson, G. L., 1975. Morphology and structure of the Southern Labrador Sea. Can. J. Earth Sci., 12:2111-2133.
Eittreim, S.L., Cooper, A.K., Wannesson, J., 1995. Seismic stratigraphic evidence of ice-sheet advances on the Wilkes Land margin of Antarctica. Sediment. Geol., 96:131-156.

Faugères, J.-C. and Stow, D.A.V., 1993. Bottom-current-controlled sedimentation: a synthesis of the contourite problem. Sediment. Geol., 82:287297.

Funder, S., and Larsen, H.-C., 1989. Quaternary geology of shelves adjacent to Greenland. In Fulton, R. (Ed.), Quaternary Geology of Canada and Greenland. Geol. Soc. Am., Geol. of North Am. Ser., K-1:769-772.

Hamilton, E.L., 1967. Marine geology of abyssal plains in the Gulf of Alaska. J. Geophys. Res., 72:4189-4213.

Hess, G.R., and Normark, W.R., 1976. Holocene sedimentation history of the major fan valleys of Monterey fan. Mar. Geol., 22:233-251.

Hollister, C.D., and Heezen, B.C., 1972. Geological effects of ocean bottom currents: western North Atlantic. In Gordon, A.L. (Ed.), Studies in Physical Oceanography: New York (Gordon and Breach), 37-66.

Howe, J.A., Stoker, M.S., and Stow, D.A.V., et al., 1994. Late Cenozoic sediment drift complex, northeast Rockall Trough, North Atlantic. Paleoceanography, 9:989-999

Johnson, G.L., and Schneider, E.D., 1969. Depositional ridges in the North Atlantic. Earth Planet. Sci. Lett., 6:416-422.

Johnson, G.L., Sommerhoff, G., and Egloff, J., 1975. Structure and morphology of the west Reykjanes Basin and the southeast Greenland continental margin. Mar. Geol., 18:175-196.

Jones, E.J.W., Ewing, M., Ewing, J., and Eittreim, S.L., 1970. Influence of Norwegian Sea overflow water on sedimentation in the northern North Atlantic and Labrador Sea. J. Geophys. Res., 75:1655-1680.

Kennard, L., Schafer, C., and Carter, L., 1990. Late Cenozoic evolution of Sackville Spur: a sediment drift on the Newfoundland continental slope. Can. J. Earth Sci., 27:863-878.

Kuijpers, A., and Duin, E.J.Th., 1986. Boundary current-controlled turbidite deposition: a sedimentation model for the Southern Nares Abyssal Plain, Western North Atlantic. Geo-Mar. Lett., 6:21-28.

Larsen, H.C., 1985. Petroleum geological assessment of the East Greenland Shelf. Groenl. Geol. Unders. Open-File Rep., 99:78.

, 1990. The East Greenland Shelf. In Grantz, A., Johnson, G.L., and Sweeney, J.F. (Eds.), The Arctic Ocean Region. Geol. Soc. Am., Geol. of North Am. Ser., L:185-210.

Larsen, H.C., Saunders, A.D., Clift, P.D., Beget, J., Wei, W., Spezzaferri, S., and the ODP Leg 152 Scientific Party, 1994. Seven million years of glaciation in Greenland. Science, 264:952-955.

Larsen, H.C., Saunders, A.D., Clift, P.D., et al., 1994. Proc. ODP, Init. Repts., 152: College Station, TX (Ocean Drilling Program).

Larsen, H.C., Saunders, A.D., Larsen, L.M., Lykke-Andersen, H., Leg 152 Scientific Party, Marcussen, C., and Clausen, L., 1993. ODP activities on the South-East Greenland margin: Leg 152 drilling and continued site surveying. Rapp. Groenl. Geol. Unders., 160:73-79.

Livingstone, H.D., Swift, J.H., and Ostlund, H.G., 1985. Artificial radionuclide tracer supply to the Denmark Strait Overflow between 1972 and 1981. J. Geophys. Res., 90:6971-6982.

Lovell, J.P.B., and Stow, D.A.W., 1981. Identification of sandy contourites. Geology, 9:347-349.

Masson, D.G., and Kidd, R.B., 1987. Revised Tertiary seismic stratigraphy of the southern Rockall Plateau. In Ruddiman, W.F., Kidd, R.B., et al., Init. Repts. DSDP, 94: Washington (U.S. Govt. Printing Office), 1117-1126.

McCave, I.N., and Tucholke, B.E., 1986. Deep current-controlled sedimentation in the western North Atlantic. In Vogt, P.R., and Tucholke, B.E. (Eds.), The Western North Atlantic Region. Geol. Soc. Am., Geol. of North Am. Ser., M:451-468.

McGinnis, J.P., and Hayes, D.E., 1994. Sediment Drift Formation along the Antarctic Peninsula. Terra Antarct., 1:275-276.

, 1995. The roles of downslope and along-slope depositional processes: Southern Antarctic Peninsula continental rise. In Geology and Seismic Stratigraphy of the Antarctic Margin. Antarct. Res. Ser., 68:141156.

Miller, K.G., and Tucholke, B.E., 1983. Development of Cenozoic abyssal circulation south of the Greenland-Scotland Ridge. In Bott, M., Saxov, S., Talwani, M., and Thiede, J. (Eds.), Structure and Development of the Greenland-Scotland Ridge: New Methods and Concepts: New York (Plenum), 549-590.

Mitchum, R.M., Jr., Vail, P.R., and Sangree, J.B., 1977. Seismic stratigraphy and global changes of sea level, Part 6. Stratigraphic interpretation of seismic reflection patterns in depositional sequences. In Payton, C.E. 
(Ed.), Seismic Stratigraphy: Applications to Hydrocarbon Exploration. AAPG Mem., 26:117-133.

Mountain, G.S., and Tucholke, B.E., 1985. Mesozoic and Cenozoic geology of the U.S. Atlantic continental slope and rise. In Poag, C.W. (Ed.), Geologic Evolution of the United States Atlantic Margin: New York (Van Nostrand Reinhold), 293-341.

Mutti, E., 1992. Turbidite Sandstones: Milan (Agip S.p.A., S. Donato Milanese).

Myers, R.A., and Piper, D.J.W., 1988. Seismic stratigraphy of late Cenozoic sediments in the northern Labrador Sea: a history of bottom circulation and glaciation. Can. J. Earth Sci., 25:2059-2074.

Normark, W.R., Hess, G.R., Stow, D.A.V., and Bowen, A.J., 1980. Sediment waves on the Monterey fan levee: a preliminary physical interpretation. Mar. Geol., 37:1-18.

Pickering, K.T., Hiscott, R., and Hein, F.J., 1989. Deep-marine Environments: Clastic Sedimentation and Tectonics: London (Unwin Hyman).

Ruddiman, W.F., 1972. Sediment redistribution on the Reykjanes Ridge: seismic evidence. Geol. Soc. Am. Bull., 83:2039-2062.

Shor, A.N., and Poore, R.Z., 1979. Bottom currents and the ice rafting in the North atlantic: interpretation of Neogene depositional environments of Leg 49 cores. In Luyendyk, B.P., Cann, J.R., et al., Init. Repts. DSDP, 49: Washington (U. S. Govt. Printing Office), 859-872.

Sommerhoff, G., 1973. Formenschatz und morpholigishe Gliederung des südostgrönlandischen Schelfgebietes und Kontinental abhanges. "Meteor" Forsch. Ergebnisse Reihe C, 15:1-54.
1979. Submarine glazial uebertiefte Taeler von Suedgroenland. Eiszeitalter Ggw., 29:201-213.

Stanley, D.J., 1993. Model for turbidite-to-contourite continuum and multiple process transport in deep marine settings: examples in the rock record. Sediment. Geol., 82:241-255.

Thompson, K.R., Lazier, J.R.N., and Taylor, B., 1986. Wind-forced changes in Labrador Current transport. J. Geophys. Res., 91:14261-14268.

Tucholke, B.E., and Mountain, G.S., 1986. Tertiary paleoceanography of the western North Atlantic Ocean. In Vogt, P.R., and Tucholke, B.E. (Eds.), The Western North Atlantic Region. Geol. Soc. Am., Geol. of North Am. Ser., 631-650.

van der Linden, W.J., Fillon, R.H., and Monahan, D., 1976. Hamilton Bank, Labrador margin: origin and evolution of a glaciated shelf. Mar. Sci. Pap. 14, Geol. Surv. Can. Pap., 75-40.

Vorren, T.O., Lebesbye, E., Andreassen, K., and Larsen, K.-B., 1989. Glacigenic sediments on a passive continental margin as exemplified by the Barents Sea. Mar. Geol., 85:251-272.

Date of initial receipt: 6 November 1995

Date of acceptance: 17 September 1996

Ms 152SR-202 